\title{
PURSUING PERMANENCE: FORMER INTERNATIONAL STUDENTS' TRAJECTORIES TO PERMANENT RESIDENCY IN CANADA
}

\author{
by
}

Bianca Gomez, B.A., Mount Allison University, 2014

\author{
A Major Research Paper \\ presented to Ryerson University \\ in partial fulfillment of the requirements for the degree of \\ Master of Arts \\ in the Program of \\ Immigration and Settlement Studies
}

Toronto, Ontario, Canada, 2017

(C) Bianca Gomez 2017 


\section{AUTHOR'S DECLARATION FOR ELECTRONIC SUBMISSION OF A MAJOR RESEARCH PAPER (MRP)}

I hereby declare that I am the sole author of this Major Research Paper. This is a true copy of the MRP, including any required final revisions.

I authorize Ryerson University to lend this MRP to other institutions or individuals for the purpose of scholarly research.

I further authorize Ryerson University to reproduce this MRP by photocopying or by other means, in total or in part, at the request of other institutions or individuals for the purpose of scholarly research.

I understand that my MRP may be made electronically available to the public.

Bianca Gomez 


\title{
PURSUING PERMANENCE: FORMER INTERNATIONAL STUDENTS' TRAJECTORIES TO PERMANENT RESIDENCY IN CANADA
}

\author{
Bianca Gomez \\ Master of Arts 2017 \\ Immigration and Settlement Studies \\ Ryerson University
}

\begin{abstract}
This exploratory study investigates former international students' experiences pursuing permanent status with the use of primary data from interviews with five individuals. Guided by the question, "what characterizes former international students' trajectories to permanent residence" and based on the understanding that discourses of exclusion and control inform immigration policies today (Fobear, 2014), personal experiences are explored as realities of temporariness in which subjects are contained by the following forms of regulation: time limits, employment specificity, and temporary legal status. Anthony Giddens's structuration theory is employed to showcase participants as "knowledgeable" (Sewell, 1992:4) and reflexive agents (Turner, 1986); how they persevere and negotiate their way to permanent residence by enacting creative strategies and enduring the emotional labour that characterize their search for and securing of 'skilled' employment while mitigating the immediate need for income, in reframing their mindsets and in their reflections upon the meaning of their pursuits for permanence.
\end{abstract}

Keywords: international students; Canada; Post-Graduation Work Permit; experiences; temporariness 


\section{ACKNOWLEDGEMENTS}

I express my deepest gratitude to Dr. Melanie Knight, my MRP Supervisor. Her guidance and feedback did wonders for this MRP, and I thank her for cheering me on particularly during the writing process. I also thank Dr. Amina Jamal for coming on board as my second reader, and for her helpful input and overall support. I would also like to extend thanks to Dr. Harald Bauder for allowing me to participate in a research workshop on international students, an experience that strengthened my determination to pursue the topic for my MRP; and to my former professor Dr. Morgan Poteet, for being among the first pillars of support and mentorship during and beyond my beginnings as an international student in Canada.

I am also extremely grateful to have landed a spot the ISS program this year, otherwise I would have never had the privilege to experience the good, the bad, and the ugly that is graduate school alongside the most supportive classmates. I thank them for friendships that have sustained my sanity throughout the year, and for their fiery backing in my own pursuit for permanence and its documentation as an MRP.

While I only utilized five experiences for this study, I would like to thank all six of my interviewees for their time and enthusiasm to participate. Their drive and resilience are sources of inspiration for others, and without their willingness to share their stories this study is void of meaning.

Finally, I am blessed to be the sister of my brother, and the daughter of my parents. I am indebted to their unwavering love and grit as we push through international student tuition fees for two kids, and through life as a family split across borders. As they have empowered me with the resources and reasons to do and to be, I dedicate this study to them. 


\section{TABLE OF CONTENTS}

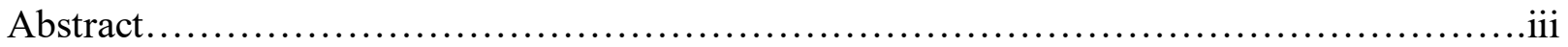

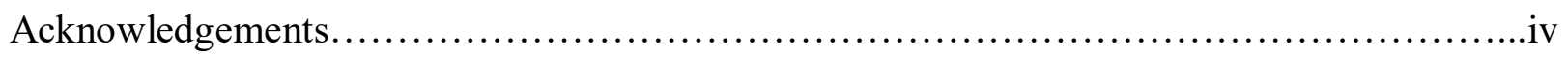

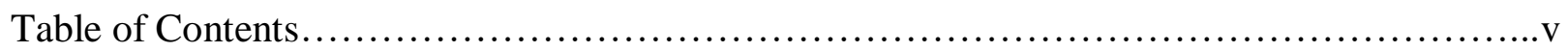

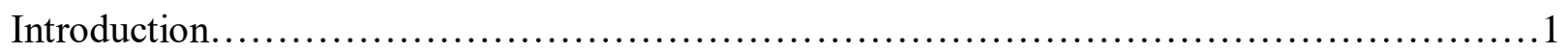

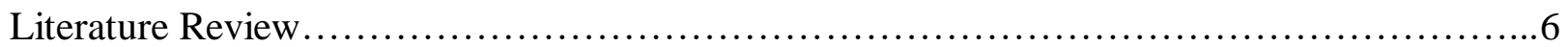

'Two-step' immigration: from temporary work permits to permanent status..............6

Types of temporary migrant workers....................................

'Two-step' immigration and 'ideal immigrants' as neoliberal constructions......8

International students in Canada: an overview...................................... 10

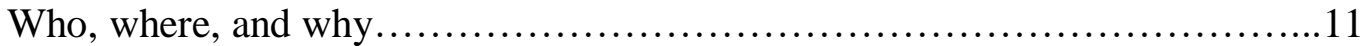

Immigration policies and pathways for international students.................12

International students before and after graduation: barriers to success................16

Lack of experience...................................................... 16

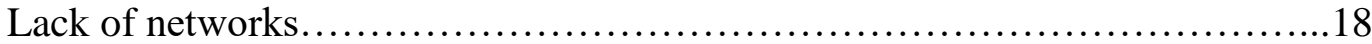

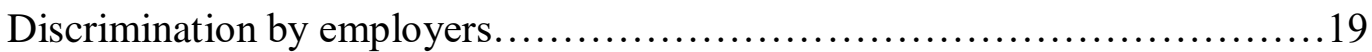

Gaps in service provisions............................................ 20

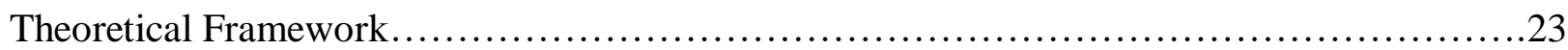

From past to present: a history of Canadian immigration............................23

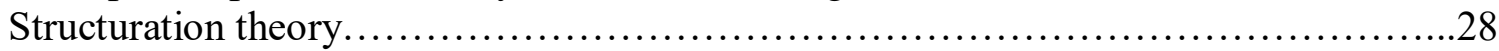

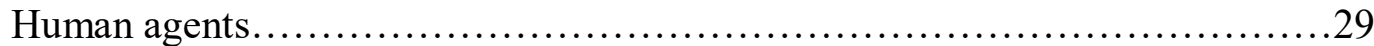

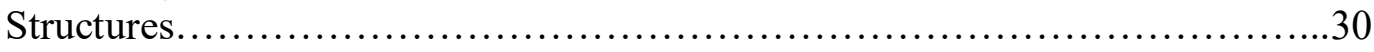

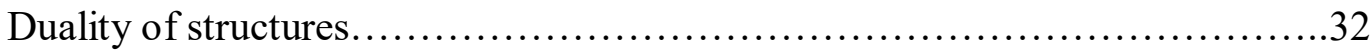

Temporariness as a manifestation of state power....................................

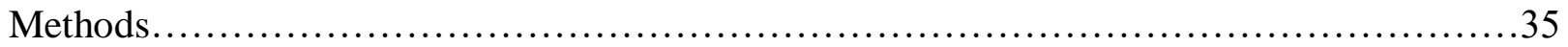

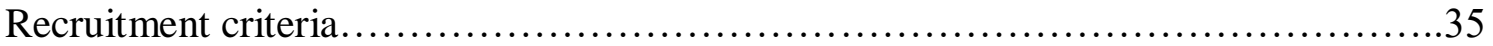

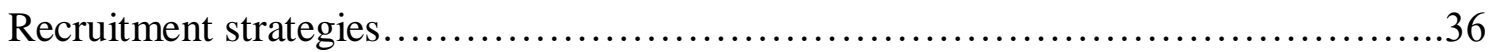

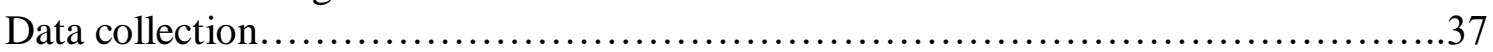

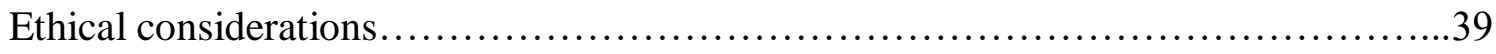

Findings and Analysis....................................................................

Demographical summary of participants..................................... 41

Prefaces to permanent residence..................................................42

Deciding to study in Canada..............................................4 43

Deciding to permanently stay in Canada..................................45

Trajectories to permanence as regulated realities...............................47

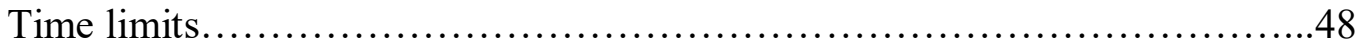

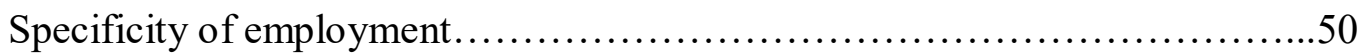

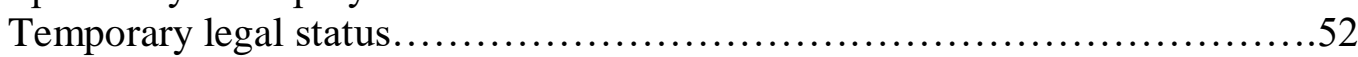

Trajectories to permanence as negotiated realities...................................57

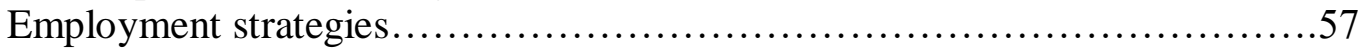

Balancing pursuits with income needs...................................60 
Re-framing mindsets...........................................63

Reflecting back on experiences............................................66

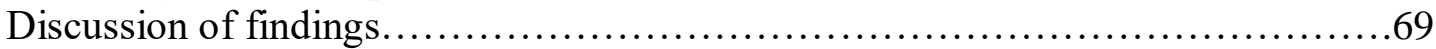

Limitations and future research........................................ 70

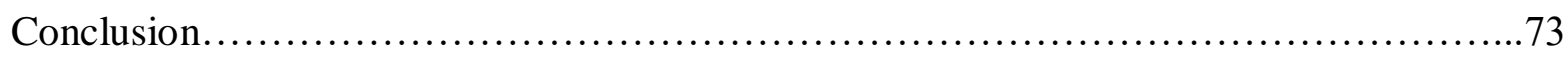

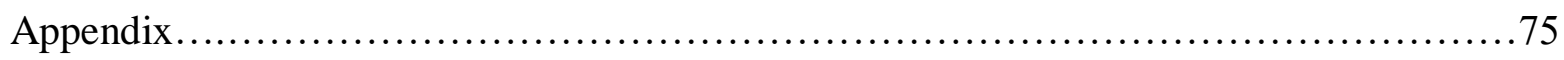

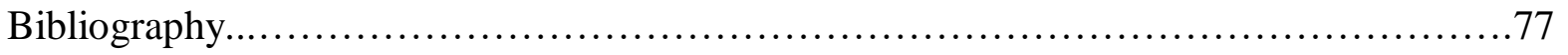




\section{INTRODUCTION}

With an estimated 4.3 million individuals crossing borders to pursue an education overseas (UNESCO, 2016), countries of destination are opening their doors to bask in this socalled 'foreign-student gold rush' (Crowley, 2014). As a known 'major English-speaking destination country' (MESDC) for study (CBIE, 2015), Canada is very much part of this picture, hosting about 3\% of the global international student population (OECD, 2015). "By virtue of their Canadian education, integration, and work experience" (Gates-Gasse, 2012:272), international students in Canada are an attractive source of long-term economic and demographical growth. This is a conjecture that underlies the "ideal immigrant" rhetoric (Cox, 2014; Gates-Gasse, 2012; Roach, 2011), imbuing Canadian immigration initiatives designed to encourage international students to stay in the country after graduation and pursue permanent residence (PR). Most crucial to achieving permanence is labour market success in the form of 'skilled work;' and as Canada's 'ideal immigrants,' their well-developed acculturation to Canadian society along with their Canadian education credentials is assumedly enough to guarantee a relatively obstacle-free ride to permanent residence.

While roughly half of all international students reportedly hope take on the opportunity to pursue permanent residence after graduation (CBIE, 2015), the intention to stay is higher than actual permanent stay rates (Gates-Gasse, 2012). Moreover, existing research has illuminated numerous barriers former international students face to employment and to labour market integration in general, which consequently adds challenges to securing permanent residence status. These discrepancies warrant further investigation into what takes place between the intention to immigrate and actually immigrating, which is what this study aims to shed light upon. Notwithstanding privileged upbringings, which entails the ability to afford and 
successfully attain education abroad, under-reported from a seemingly win-win scenario are the experiences of former international students after graduation as they pursue the laborious process of 'qualifying' for permanent status. This study also stems from my own story as a former international student in Canada, one that bears similarities to those I am privileged to share as part of this study.

\section{My post-graduation experience}

I was eighteen when I first stepped foot onto the soils of a small university town on the Atlantic coast, which was to be my home for the following four years. During my time as a student I did not care to think too much beyond graduation. I bought into the impression that Canada 'desired' international students, and combined with naiveté on my end I was assured that my post-graduation prospects for permanent status would be well-accommodated by policy. I thus allowed myself to be heavily and happily preoccupied with school, and I knew I wanted to return. Pragmatically, it was best to think about graduate studies after immigrating as the tuition fees are far more affordable as a domestic student. After securing my diploma I secured my PostGraduation Work Permit, giving me three years in Canada. I immediately moved to Toronto to be 'in the centre of it all' - to immerse myself where I thought the best professional and personal opportunities were.

It was integral that I found 'skilled' work and gather a year's experience in order to qualify for permanent residence. Year one on my permit was mostly hopping from one 'unskilled' job to the next, balancing the long-term plan with the short-term need for continuous income: I had worked as a barista, as a restaurant server, a street marketer, in retail, and in insurance. During my off-hours, I engaged with volunteer work and several passion projects. While I did not forget to enjoy myself, every move was in the hopes that I was one credential or 
professional relationship closer to finding qualifying work. Year two came the overhaul of the federal immigration system with Express Entry. Around this time I had settled down with several commitments in which my chances for qualified employment were most promising, vis-à-vis my fruitless search for jobs thus far. Again, convinced that as a former international student I would be 'taken care of,' I did not believe the changes in policy negatively affected me. I also reassured myself that sticking to my commitments would give me the professional leverage to qualify for the job I needed before the year ended. At the same time, I kept on with my job search to cover my bases.

Year three was upon me, and I was far from my original plan. The 'Canadian' experience I built over a total of seven years has not yielded success with any entry-level 'skilled' employment. I was conflicted, and it was becoming a real possibility that I was to leave Canada by the end of my permit, a frightening prospect that entailed leaving a life that I was building. Moreover, given the lack of success as far as immigration was concerned, I was questioning the worth of everything I had done thus far - seeing international student friends I graduated with well on their way to permanent residence, I felt like a failure. The decision to go to graduate school came from my desire to push forward with plans for my own life, permanent resident or not.

\footnotetext{
About this study

My experience is one of many, a micro illustration of the pursuit for permanent residence in Canada. This study investigates the experiences of former international students as they pursue permanent status with the use of primary data from interviews with five individuals. The aims of this study is to contribute to the growing literature on international students' post-graduation experiences in Canada, specifically to the body of studies that document their pursuits for
} 
permanent residence. This study focuses on the micro-level, experiential aspect of the postgraduation journey by capturing subjects' day-to-day thinking processes, and the emotional labour that does not often get documented but is very much a large part of the general immigrant experience. Moreover, by presenting findings grounded in subjective realities, this study advocates international students as the epistemic sources for the immigration policies and practices that target them.

I begin this study with a review of the literature on Canada's approach to contemporary economic immigration, the programs in place that specifically target international student retention, and existing challenges regarding former international students' labour market success and long-term integration. I situate this contemporary picture historically using a critical approach that frames Canada within its history of violent exclusion and control of non-whiteness. Based on the understanding that discourses of exclusion and control inform immigration policies today (Fobear, 2014), I explore their emanation as regulatory power that infringes upon the full enactment of participants' agencies as they pursue permanent status.

Personal experiences are explored as realities of temporariness, "testing grounds" (Rajkumar et. al, 2012:486) for permanence imposed upon and regulated by the Canadian state. Anthony Giddens' structuration theory is employed to explore how the state's regulatory power manifests as 'temporariness' in day-to-day lives, and how participants persevere by acting as "knowledgeable" (Sewell, 1992:4) and reflexive agents (Turner, 1986) to balance their courses of action towards permanent residence with their personal biographies. Guided by the question, "what characterizes former international students' trajectories to permanent residence," participants' personal stories reveal similar obstacles that manifest as material, mental and emotional trials, all of which emanate from their limited time and resources as 'temporary' 
migrants in Canada. These stories also showcase the creative ways in which these trials are confronted and overcome. In the face of time limits, employment specificity, and their temporary legal status, all of which work together to enforce participants' realities of temporariness, participants demonstrate immense creativity and resilience in the strategies and the emotional labour that characterize their search for and securing of 'skilled' employment while mitigating the immediate need for income, in reframing their mindsets and in their reflections upon the meaning of their pursuits for permanence. 


\section{LITERATURE REVIEW}

This section provides the research context to this study, beginning with an overview of Canada's immigration as a 'two-step' apparatus in which individuals are first admitted into the country as temporary migrants, and once socially and economically integrated, transition to permanent status. I describe the neoliberal foundation of this approach and the related rhetoric of the 'ideal immigrant.' I move on to an overview of the international student presence in Canada, and immigration initiatives that specifically target international student retention after graduation. This section ends with a review of existing literature on international student experiences in the labour market, particularly the barriers they face regarding their successful integration, and thus their transition to permanent status.

\section{'Two-step' immigration: from temporary work permits to permanent status}

The increasing mobility of populations through contemporary borders has led to temporariness being a fact of life. Given that individuals with citizenship in one country are working, studying, and/or residing in another, "temporariness is being institutionalized as a condition acceptable for growing numbers of people worldwide" (Latham et. al, 2014:3). On Canada's end, ever since Confederation and the beginnings of its capitalist expansion and nation building project in the 1800 s, immigration has always been an importation tool for foreign labour to fill economic roles that Canadian nationals do not want (Austin and Bauder, 2012). Unlike the recent past in which individuals would be granted permanent resident status before entering the country, the shift to a 'two-step' approach in immigration in the mid-1980s entailed high numbers of individuals, particularly with in-demand human capital, being admitted as temporary migrants and while in the country, transition into permanent status (Valiani, 2013; Roach, 2011). 
In more recent years, these numbers have surpassed the admission of permanent residents into Canada (Valiani, 2013).

\section{Types of temporary migrant workers}

The presence of any individual in Canada who is neither a citizen nor a permanent resident is legally authorized by a permit. This permit defines the purpose of their stay and for how long, rendering permit holders as legally temporary and legally obliged to act within the parameters of their permit. Thus, those who are in Canada for the purpose of employment have work permits; and as there are different categories of work permit programs, there are different types of temporary migrant workers ${ }^{1}$. Those in the Seasonal Agricultural Worker Program (SAWP) and the Live-in Caregiver Program (LCP), for instance, are given 'employer specific' work permits that tie them to a certain employer and sometimes type of employment, and to a specified length of time they can work. 'Employer-specific' work permits are also often granted to those in the Temporary Foreign Worker Program (TFWP). As Canada's means to alleviate job shortages in a range of sectors, the TFWP allows Canadian employers to hire foreign nationals from abroad or who are already in Canada (IRCC, 2012). International student graduates who wish to stay in Canada to work are given the Post-Graduation Work Permit (PGWP).

Generally speaking, temporary migrant workers' ability to apply for permanent status is contingent on the type of work permit. While the short-term nature of the SAWP disqualifies workers from permanent residence, LCP workers may apply for permanent status given they meet very specified conditions, including the controversial live-in requirement. TFWP workers are also tied to specified conditions as per their permits, but if they meet the requirements of any

\footnotetext{
${ }^{1}$ Not to be confused with those under the TFWP, I will use the term 'temporary migrant worker' or 'temporary migrant' in reference to any work-permit holder in Canada. This includes international student graduates who have left their student status and currently hold a work permit.
} 
economic immigration category, provincial or federal (detailed in the next subsection below), they can transition to permanent status.

In comparison to the above categories of temporary migrant workers, international students are given the bigger piece of the pie with the open Post-Graduation Work Permit (PGWP). The PGWP is exclusive to all those who have graduated from most Canadian postsecondary institutions ${ }^{2}$. The PGWP is unlike other work permits in that it is an open permit system that requires no job offer nor is limited to a specific field of employment (Government of Canada, 2008). All international students automatically qualify for the PGWP upon graduation and may work anywhere in the country for a maximum of three years, depending on the length of their program of study ${ }^{3}$. Like those on the TFWP, it is while on this permit international students qualify themselves for permanent residence via any category of economic immigration.

\section{'Two-step' immigration and 'ideal immigrants' as neoliberal constructions}

The 'two-step' process is imbued with a discursively neoliberal approach in that authorizing temporary migration equates low production costs and high net returns. State-society reconfigurations first began taking on a neoliberal colour in the 1980s (Arat-Koc, 1999b), in which the state removes itself out of the day-to-day concerns of civil society and leaves control to the natural dynamics of the market, the mechanisms used to advance economic growth and "national competitiveness in the context of economic globalization" (Simmons, 1999:53; cited in Bauder, 2008:131). In the context of immigration, immigrants with high levels of human capital are embraced as the key to Canada's economically driven agenda, particularly due to their ability

\footnotetext{
${ }^{2}$ Public colleges, technical/trades schools, and universities that are considered 'designated learning institutions' by the provincial or territorial government allow its international student graduates to apply for the PGWP. In the case of private post-secondary institutions (at least outside Quebec), they must have authorization to "legally award degrees under provincial law (for example, Bachelors, Masters or Doctorate)" (IRCC, 2017a). Beyond the institution type, exceptions lie in the nature of the program of study - for instance, international students who graduated from programs of less than eight months or who studied on a part-time basis are not eligible for the PGWP.

${ }^{3}$ The program of study must be a minimum of eight months, meaning that its graduates would receive a work permit valid for eight months. A four-year degree qualifies for a three-year work permit (IRCC, 2017b).
} 
to be self-reliant in their integration. This valorization of individual "market-oriented values such as self-reliance" (Arat-Koc, 1999b:34) is central to the rhetoric of 'designer,' or 'ideal' immigrants: highly skilled individuals who, by way of their Canadian credentials and time spent in Canada prior to permanent immigration, are self-sufficient in their preparation for and integration into Canadian life (Cox, 2014; Gates-Gasse, 2012).

In pushing market productivity while dissociating from the duty to provide welfare, embodying the neoliberal approach to immigration is the 'maximization' of immigrants' economic contributions while "minimizing their costs in settlement" (Arat-Koc, 1998:49, cited in Roach, 2011:5). The process of integration is thus the sole responsibility of the individual - just as the 'good (neoliberal) citizen' acknowledges "the limits and liabilities of state provision" and willingly takes on the "obligation to work longer and harder to become more self-reliant" (Brodie 1996:131; cited in Arat-Koc, 1999b:34), the 'ideal immigrant' is also expected to be self-sufficient in her settlement and subsequent contribution to Canada's global competitiveness, hence the redundancy to support the integration of the 'ideal immigrant.' As far as immigration policy is concerned, the 'ideal immigrant' is capable of, thus is responsible for, her own success in the labour market, thereby in her demonstration to the state that she is worthy of permanence in Canada.

Thus, those on temporary work permits, including the PGWP, do not qualify for certain entitlements such as federal service provisions ${ }^{4}$ (CCR, 2016a). The 'two-step' approach ensures

\footnotetext{
${ }^{4}$ For instance, temporary migrants cannot vote nor run for office, and are ineligible to apply for government jobs and other occupations that are federally funded. They also cannot receive settlement services provided by federal funds. Depending on the province/territory, this may mean barred access to a range of services that may help their integration into Canada, such as language training; or grant them protection and justice from abuse and vulnerability, such as legal support and individual counselling (CCR, 2016b). Temporary migrants may qualify for certain entitlements as long as it is within the jurisdiction of the province/territory. In Ontario, temporary migrants on long-term permits are eligible for OHIP, but are excluded from OSAP. Regarding provincially-funded settlement services, Twenty percent of settlement services in Ontario are funded by the province while eighty percent is funded by the federal government (Roach, 2011:18). However, with a \$53-million budget cut from the federal government,
} 
a pool of high-skilled and self-sufficient individuals who, most importantly, provide flexible labour as per the "plans and needs of employers" (Valiani, 2013:58). 'Flexibility' connotes workers who are as "adaptable to the needs of the labour market" (Bauder, 2008:145) as much as they are disposable (Fudge and Macphail, 2009).

\section{International students in Canada: an overview}

Marginson (2011) notes that "international education is a global exchange where the student is nominally valued and welcomed" (500). Combining the "exponentially higher tuition fees" they pay compared to domestic students, along with living and day-to-day expenses (Roach, 2011:10), the international student presence translates into billions of dollars in revenue annually for the local economy (IRCC, 2016c). International student expenditures in 2010 alone reportedly generated over 445 million dollars in government revenue, and contributed over 8 billion dollars to the local economy, surpassing that of exports of unwrought aluminum or of helicopters, airplanes, and spacecraft (Roslyn Kunin \& Associates, 2012). 'International campuses' are also promoted as keystones of national economic competitiveness due to international students bringing with them "new ideas and cultures that enrich the learning environment" (ibid.; Fama, 2011).

While the benefits of hosting a large international student presence are acknowledged and capitalized upon by many destinations of study, Canada takes a step further than most by providing international students the opportunity to become permanent residents and eventual citizens. Canada deems international students as 'Canadian' human capital in the making, the idea that underpins their image as 'ideal' immigrants upon graduation (Zilio and Chiose, 2016). With labour market shortages and the imminent threats posed by an aging and shrinking

it has become "increasingly difficult for some immigrant serving agencies to provide international students, and immigrants more generally, with the services to help them get established in Canada" (ibid.). 
population, international students are 'most preferred' compared to other migrants due to their well-preparedness for the Canadian labour market and their ability to "integrate quickly into Canadian society," all of which are "primarily due to their Canadian educational credentials" (IRCC, 2016c).

What follows is an overview of the international student presence in Canada and given their image as 'ideal immigrants,' immigration initiatives in place that serve to retain international students as permanent residents after graduation.

\section{Who, where, and why}

In his historical case study of international students in Canada post-WWII, Cameron (2006) documents how "international students have been studying at Canadian universities in small numbers since the 1800 s [...] [and estimated at] about 6,000 in $1950 \ldots "(1-2)$. Guruz (2011) presents UNESCO data on Canada that shows enrolment numbers of 8,518 in 1962, which more than doubled in 1968 at 17,424. In this same year, Canada ranked fifth in the list of top ten host countries for foreign students ${ }^{5}$, after the United States, France, Germany, and Lebanon (ibid.).

While Canada's global ranking has fallen to eighth place today (UNESCO, 2016), numbers in enrolment have increased from 28,443 in 1980 to 96,500 in 2001; and further up to 135,549 in 2007 (Gürüz, 2011). Between 2010 and 2013, Lu and Hou (2015) report about 385,000 international admissions across all levels of education, 63 percent of which were postsecondary students (an estimate of 242,550). In the 2012-2013 academic year, out of the entire post-secondary student population nationwide, 11 percent were international (CBIE, 2015).

\footnotetext{
${ }^{5}$ Guruz borrows UNESCO's 1971 definition of 'foreign student' as a "person enrolled at an institution of higher education in a country or territory of which he is not a permanent resident" (2011:201).
} 
Moreover, in 2015 alone a little over 125,700 new study permits were issued to international students, “a 5.4\% increase from 2014” (IRCC, 2016c).

Equally as significant is the national diversity among international students. The 1980s witnessed flows and stocks ${ }^{6}$ dominated by students from Hong Kong, the United States, Malaysia, and Japan (Iturralde and Calvert, 2003). Flows from Hong Kong and Malaysia declined going into the millennium as new countries of origin enter the picture; in 2004, the top five countries of origin were China, the United States, France, India, and South Korea (Gürüz, 2011). There was little change since, as China and India are currently the leading countries of origin of international students enrolled in universities and colleges, followed by France, the United States, Saudi Arabia, and South Korea (CBIE, 2015). Across all levels of education, the fastest growing demographics are students from Nigeria, Brazil, and Vietnam (ibid.). Canada's biggest points of attraction for international students include 'quality education' of an "Anglo-Saxon type $[\ldots]$ at considerably low costs compared with private US institutions" (Gürüz, 2011:211); and the country's reputation as "safe," "tolerant," and "non-discriminatory" (CBIE, 2015; CBIE, 2009). Employment and permanent residency opportunities after graduation are reported to be incentives as well, albeit more popular among college students than those in university (CBIE, 2009).

\section{Immigration policies and pathways for international students}

As aforementioned, upon request international students are granted a Post-Graduation work permit that allows them to work anywhere in Canada in any job for a length of time contingent on their program of study. On this permit, permanent residency is accessible via any category of immigration on both the federal and provincial levels, provided the candidate meets

\footnotetext{
${ }^{6}$ Flows is the number of international students "entering the [federal] system for the first time." Stocks is the number of international students in the system "on a specific date in each year of observation" (Iturralde and Calvert, 2003:2).
} 
the qualifications for application. While acknowledging non-economic immigration such as family and spousal sponsorship, refugee and asylum seekers, this study focuses on Canada's economic immigration categories through which temporary migrants on work permits, including former international students, can apply.

Categories for economic immigration are either federal, now accessible via the bigger apparatus known as Express Entry, or provincial. Prior to Express Entry, the federal categories for to permanent residency for economic immigrants were relatively straightforward. Applications were submitted into one of the following: Federal Skilled Workers (FSW), Federal Skilled Trades (FST), and Canadian Experience Class (CEC); and each had a standardized criteria against which applicants were assessed on a pass/fail basis. The pre-Express Entry trajectories for permanent residence or for temporary work permit holders on the federal level are summarized in Figure 2.1 below. The CEC will be the focus of this discussion as it was initially launched to target the retention of graduated international students.

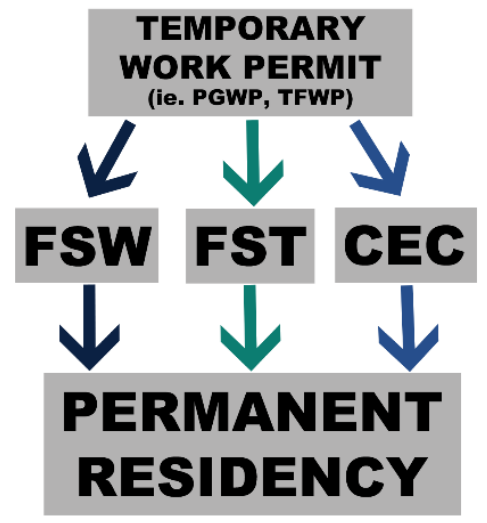

Figure 2.1 - Federal pathways to permanent residence for temporary work permit holders (before Express Entry) ${ }^{7}$

The CEC was launched in 2008 to address the "strong need for an increased supply of skilled workers" (IRCC, 2016d) due to evidence that suggests "skilled workers with Canadian

\footnotetext{
${ }^{7}$ While there are special cases (such as LCP workers who pursue the new classes of caregiver work, Caring for Children or Caring for People with High Medical Needs (IRCC, 2017d)), for simplicity I indicate the PGWP and TFWP as temporary work-permit programs in which workers can qualify for permanent residence.
} 
work or Canadian work and study experience had better economic outcomes than those without" (ibid.). Roach (2011) posits that such evidence is inconclusive; none the less the CEC is promoted as a "simple and quick pathway to permanent residency" (ibid.) for those on the TFWP and international students. Eligibility for permanent residence is contingent upon firstly, meeting required proficiency levels in English and/or French, in the areas of speaking, reading, writing and listening (IRCC, 2016a). Secondly, applicants must "have at least 12 months of full-time (or an equal amount in part-time) skilled work experience in Canada in the three years before [applying], [done] with the proper authorization" (ibid.). 'Skilled work' falls under one of three 'skill types' defined by the National Occupation Code: managerial (skill type 0), professional (skill type A), and 'technical' or 'skilled trades' (skill type B) (ibid.). 'Proper authorization' requires applicants to have been on a work permit, usually being the PGWP in the case of international students.

Direct access to the federal streams ceased since the initiation of Express Entry in January 2015, illustrated below in Figure 2.2. Under this new system, eligibility for permanent residence heightens beyond a pass/fail basis. While applicants still have to meet the original requirements of any one federal stream, Express Entry generates a numerical score for each candidate based on her human capital factors ${ }^{8}$, known as the Comprehensive Ranking System (CRS) score. On top of human capital factors, the candidate can receive additional points up to a maximum of 600 if she has a job offer with a positive Labour Market Impact Assessment $(\text { LMIA) })^{9}$ and a Provincial Nomination (which will be further elaborated below); and implemented just last year, points for siblings in Canada, French language skills, and a

\footnotetext{
${ }^{8}$ Express Entry measures the following human capital factors: age, level of education, proficiency in English and/or French, and Canadian work experience (IRCC, 2017c).

${ }^{9}$ Formerly known as a Labour Market Opinion (LMO), the Labour Market Impact Assessment (LMIA) is required of the employer to hire a foreign national. This is a certification process that requires the employer to demonstrate there is a shortage of Canadian workers in a specific occupation (IRCC, 2017e).
} 
postsecondary education in Canada. Express Entry then compares candidates of all streams against one another on the basis of their scores, and those who score above a certain cut-off receive an Invitation to Apply (ITA). Every two weeks ITAs are allotted, and for each round the cut-off varies.

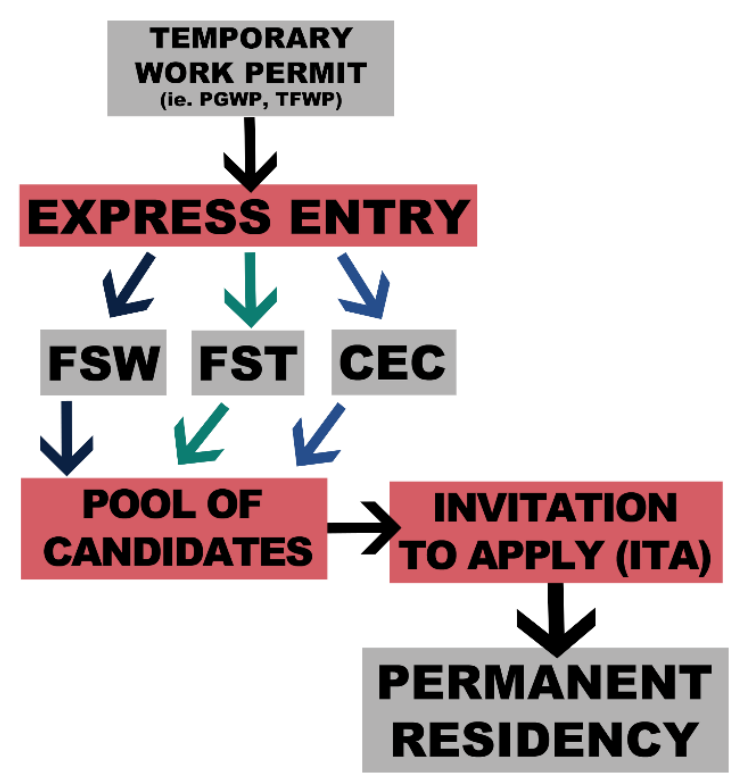

Figure 2.2 - Federal pathways to permanent residence for temporary work-permit holders (under Express Entry)

Besides Express Entry, international students can also apply through any Provincial Nomination Programs (PNP) of the province they are currently residing. PNPs are immigration pathways on the provincial level, and most have sub-streams designed to retain international students who have graduated from a postsecondary institution in the respective province. For instance, Ontario, Alberta and British Columbia have streams for 'international students with a job offer' - the offer being from an employer within the province (Province of Ontario, 2017; Province of Alberta, 2017; Province of British Columbia, 2017). International student streams in Saskatchewan, Newfoundland and Labrador requires applicants to have a job offer in their field of study (Government of Saskatchewan, n.d.; Government of Newfoundland and Labrador, n.d.); and applicants for Manitoba's program must be currently working for an employer who has offered them a "permanent (long-term) full-time job" (Province of Manitoba, n.d.). 
Since 2015, many PNPs have launched Express Entry versions of their streams (IRCC, 2016b). Applicants either apply through the province or territory first, then enter Express Entry with a nomination; or provinces and territories send to those already in Express Entry an offer of nomination, given that applicants indicated the same province or territory of interest in their application. In both cases, nominations are awarded a maximum of 600 points on top of their CRS scores, essentially a guarantee they will exceed the average cut-off and receive an ITA.

\section{International students before graduation and after: barriers to success}

As per the 'ideal immigrant' rhetoric, a crucial qualifier for permanent residence is labor market success. A neoliberal paradigm that has seeped into immigration policy and settlement initiatives since the 1970s (Roach, 2011; Cox, 2014) has left the onus on the international student to demonstrate she qualifies for permanent settlement via securing employment, specifically 'skilled' employment. Studies identifying a multitude of barriers experienced in the labour market after graduation, however, pose a significant challenge to the state rhetoric that associates an almost automatic success on the part of international students. The three most cited barriers are the lack of work experience, the lack of networks, and discrimination by employers.

\section{Lack of experience}

In their study of international student transitions from student to worker, Arthur and Flynn (2013) report that most of their interviewees indicated the lack of Canadian work experience as a common barrier to employment after graduation. A majority of the literature that involved international student interviewees cited the same challenge (ie. Scott et. al, 2015; Kelly, 2012; Cobb, 2012; Nunes and Arthur 2013) and pointed further to the significance of attaining work experience during their studies in Canada. In some cases, it is a matter of understanding, or being aware, that Canada has a particular culture of working while studying. Several participants 
in a study by Kelly (2012) did not have this knowledge, having arrived to Canada without any prior working experience, or graduating from their studies in Canada "without ever having worked" (31). In the cases of those who pursued or secured employment while studying, a number of challenges were realized in hindsight. One was the difference between on-campus and off-campus work experience. While on-campus work experience is indeed valuable, especially in building networks (to be discussed further); when it comes to a matter of exposure to employers (Gates-Gasse, 2012) and employment as related to one's area of study, having a work history of only on-campus jobs makes it "difficult to transition to work out of an educational institution upon graduation" (Kelly, 2012:32).

Another interrelated challenge is securing work experience in one's field of study. The literature is unanimous in claiming that having access to co-ops or placement are integral to acquiring relevant work experience (ie. Bond, 2007; Kelly, 2012). However, many international students "were not offered practicum or internship opportunities" (Scott et. al, 2015: n.p.) due to limited positions available or the program of study reserving such opportunities for permanent residents or Canadian citizens (Kelly, 2012).

In order to ensure a relatively unhindered transition into the Canadian labour market, work experience prior to graduation is crucial in at least two respects. First, most employers look for Canadian work experience, more so than the completion of a degree (Gates-Gasse, 2012; Kelly, 2012; Roach, 2011). Second, exposure to the Canadian workplace conditions international students to "the unwritten norms of behavior, especially non-verbal behaviors" (Bohonos, 2009:47; cited in Gates-Gasse, 2012:276). An understanding of the workplace culture prior to any job search can mitigate micro-scale tensions that may arise in first-contact scenarios with 
employers such as interviews, in which "a firm handshake," "good eye contact," or "positive self-talk" goes a long way (Gates-Gasse, 2012:277).

\section{Lack of networks}

Access to work experience is facilitated by having a substantial professional and personal network; yet networks are built through employment and work experience. The lack of both also presents itself as a 'chicken or the egg' scenario: if international students do not have work experience, their circle of networks remains limited; yet if they do not have networks, they are less exposed to opportunities that could aid them in acquiring employment experience. The same factors that aggravate the lack of work experience is thus similar for the lack of networks - little to no access nor exposure to work off-campus and to co-op or placements during studies constricts opportunities to network with employers and industry insiders; creating such connections during one's studies and nurturing them over time are key to finding employment after graduation. In the best case scenario, co-op or placements lead to a job offer with the organization upon completion of studies (Kelly, 2012). To quote one participant in a study by Scott et. al (2015), "it's about "who you know, not what you know"” (n.p.).

However, the postsecondary campus is not completely void of opportunity. Cobb (2012) highlights the role of volunteerships, student group membership and other extracurricular activities throughout one's university or college career in helping students make networks, which eventually lead to off-campus opportunities and an arsenal of connections to draw upon when the search for employment after graduation begins. Similarly, job fairs on campus and networking events open (or deliberately advertised) to international students (Arthur and Flynn, 2013) offer the chance for them to survey and explore potential employment opportunities, if not directly interact with potential employers (Nunes and Arthur, 2013). 


\section{Discrimination by employers}

The third major barrier to employment is discrimination by employers against hiring international students. Respondents in existing studies describe how misunderstandings with employers have been based on assumptions around international students not being proficient in English (Nunes and Arthur, 2013) and not being knowledgeable about Canadian workplace norms due to a lack of work experience, especially when it comes to experience in a specified field (Kelly, 2012). Even in the case of co-op opportunities or placements during studies, hesitancy on the part of employers to hire international students is also an issue, especially if there is a pool of domestic students available at the employers' disposal (ibid.). Career counsellors interviewed in a study by Roach (2011) also mention that employers are intimidated by the process of recruiting international students; a participant is quoted in saying that she tells international students not to let employers know they are international. Employers interviewed for Bond's study (2007) cited an expectation of associated legal risks or an overestimation of bureaucratic hurdles involved (ibid.). Lack of citizenship status is thereby regarded as inhibiting employers from hiring international students (Nunes and Arthur, 2013), reflecting the link some international students may make between permanent or citizenship status and "more options, more good jobs" (Cobb, 2012:37). The fact that international students are in Canada for a limited time creates a belief that employers will not hire them because it "is not worth the time and effort" (Bond, 2007).

There is a strong suggestion that most employers may simply be uninformed. Outdated or inconsistent information on government websites (Bond, 2007) on how to recruit international students, and on postsecondary websites (Gates-Gasse, 2012) regarding work authorization can confuse, mislead and subsequently discourage employers from reaching out. Some employers 
may not even be aware that hiring international students is an option (Bond, 2007). Projects have been launched to target educating employers and bridge them with international students, indicating the importance of networking opportunities between the two parties. For instance, the Government of Newfoundland and Labrador offers a guide that informs employers on not just the hiring process, but on how to approach micro-level nuances such as conducting interviews with a candidate whose first language is not English (Gates-Gasse, 2012). SolutionsNB by the province of New Brunswick includes opportunities for employers to contact postsecondary institutions and connect with their international student community (ibid.); and the 2006 International Students' Post-Graduate Project in Halifax comprised of a networking lunch that allowed international students and employers "to meet and speak [...] discuss areas of interest, and circulate resumes" (ibid, 2012; 284).

\section{Gaps in service provision}

Several studies done on service provisions available to international students during and after their studies demonstrates a severe lack of support targeted towards their long-term integration. Support for employment, academics and language, and social and emotional concerns are essential to mitigating the trials that first emerge during school and sustain after graduation (Gates-Gasse, 2012:277-280) in the forms of the aforementioned labour market barriers.

The root of these challenges are gaps in funding for on-campus services and limited access to settlement services after graduation (Gates-Gasse, 2012:289-290). In her research of services in postsecondary institutions in Toronto, Roach finds that staff are "overburdened" they are ill-equipped to "[expand] the services they [already] provide" (2011:32) and there is a lack of services beyond "supporting academic success and day-to-day pragmatic issues" (ibid.). 
Because "early intervention improves social and labour market integration" (Gates-Gasse, 2012:290), it is essential that postsecondary institutions are able to support long-term immigration and integration needs. However, as immigration advice is considered 'legal advice' (Roach, 2011:33) and its provision requires certification, such resource is rarely in-house (ibid.). Further, after graduation, international students are not eligible for federally-funded services and some provincial services (Gates-Gasse, 2012:290). International students can attend workshops but are restricted from accessing personalized, one-on-one consultations (Roach, 2011:31).

Roach (2011) identifies neoliberalism as driving the contradiction between "the ineligibility of international students for [certain services]" and "the state desire to retain [them] as immigrants" (Gates-Gasse, 2012:290). Immigration that "embrac[es] the competitive principles of economic globalization" (Roach, 2011:4) has led to pursuing 'highly skilled' immigrants who "would not only benefit Canada economically, but also bolster Canada's global competitive advantage" (ibid., 2011:5).

Yet while neoliberalism calls for "maximizing immigrants' economic contributions" (Arat-Koc, 1998; cited in Roach, 2011:5), it warrants "minimizing their costs in settlement and welfare" (ibid.). Roach describes this as the "devolution of [state] service delivery" (2011:2); and by Gates-Gasse as the "downloading" of responsibility "for immigration selection and support onto the provinces, postsecondary institutions, and employers" (2012:291). Like all neoliberal tenets (Roach, 2011:29), its application lacks coordination between levels of government and service providers (Gates-Gasse, 2012:290), resulting in differential provisions between postsecondary institutions (Roach, 2011:29); provisions of "an ad hoc basis" (Roach, 2011:49); scarce funding (Gates-Gasse, 2012:289); and overall disorientation around who is responsible for international students and their success as potential immigrants (ibid., 2012:290). 
Evidently in place are successful initiatives that are designed to incentivize international students to pursue labour market participation after they graduate. Initiatives have yielded some success, as the rate of those who change their statuses from that of a student is approximated at $33 \%{ }^{10}, 80 \%$ or more of whom did so for work-related reasons. This is higher than the average 'stay rate' of 25\% among most countries (OECD, 2011). However, as much as the PGWP was founded upon the reasons Canada embraces the international student presence, the permit system's lived realities and disadvantages ultimately speak to how international education "triggers border anxiety, bureaucratic categorization and coercion" (Marginson, 2011:500). International students are still citizens of other nations engaging in the bigger picture of "global people flows [Canada can] never fully control" (ibid.) of which temporariness is the platform.

While the literature recognizes the neoliberal paradigm that infuses the contemporary state to maintain international students as temporary in order to exploit them into material gains before their transition to permanent status, this study intends to look more closely at temporariness as a space contained within multiple systems of oppression that span space and time. Temporary migration today should be understood as continued from the past ${ }^{11}$; and as much as challenges encountered by international students and temporary migrant workers in general regard issues of legal restrictions and lack of services that render them a flexible and commodifiable pool of labour, the other ways in which temporariness is a highly oppressed space warrants exploration.

\footnotetext{
${ }^{10}$ Though it is not definite, the OECD estimates that these students who change their statuses are those who have most likely graduated (2011).

${ }^{11}$ For instance, while the idea of the 'ideal immigrant' is "distinctly neoliberal" (Cox, 2014:29), its central tenet of self-sufficiency has always been one way or another a part of the immigration discourse since the colony years (ibid.). Canada's first Immigration Act of 1869, for example, prohibited the admission of individuals who did not have the financial means to support themselves upon arrival (Kelley and Trebilcock, 2010). While not always enforced uniformly, self-sufficiency was also in the criteria for immigrant recruitment for the purpose of populating the Canadian West - immigrant agents were dispatched to advertise the frontier to agriculturalists who had the means to establish themselves (ibid.).
} 


\section{THEORETICAL FRAMEWORK}

In this section, I lay the groundwork for the exploration of temporariness as a stateimposed and regulated space. I contextualize economic immigration today with the story of Canada's emergence based on the institutionalized containment, exploitation and exclusion of 'non-whiteness.' This critical approach sets the macro framework for exploring how 'temporariness' today serves as a "testing ground" (Rajkumar et. al, 2012:486) for those who are 'not Canadian,' as an instrument of regulation that shapes the realities of former international students as they pursue permanent residence status. I then describe Anthony Giddens' structuration theory to employ it as an analytical lens on the micro level to examine how former international student subjects negotiate their individual agencies with various manifestations of state regulation to reclaim control in their daily lives.

\section{From past to present: a history of Canadian immigration}

Canada is a nation founded on a history of violence and exclusion - from the preConfederation centuries that are characterized by the dispossession of Indigenous land, the enslavement of Aboriginals and Blacks and their erasure from Canadian national identity and belonging (Kelly, 2017), to immigration policies that were "racist and exclusionary" towards non-white immigrants that lasted well into the 1960s (Kelley and Trebilcock, 2010:466).

According to Fobear (2014), migration into Canada has always been informed by a "racial story" (n.p.). Before Canada became a nation in 1867, it was a conglomerate of French and British colonies that were just "a little more than trading posts" (Kelley and Trebilcock, 2010) that later extended into a settlement project in which immigration served as a "recruitment and settlement policy that was designed to populate land surrendered by Aboriginals" (Kelly, 2017:12). Undergirding the years to Confederation is a storyline "in which European settlers are 
seen as the bearers of civilization, transforming and ultimately saving the land from its so-called primitive or savage past" (Fobear, 2014:n.p.). At the same time, this is a storyline that excludes one of the first histories migration into Canada by Black refugee slaves, their importation into Canada as slaves by White settlers, and the roles Blacks had in laying the foundation for the Confederation. Despite fighting alongside White soldiers in the American Revolution of 1812, for instance, they were 'rewarded' with land plots that were "essentially sterile and remote and were significantly smaller than the plots allowed to White farmers" (Kelly, 2017:14). Africville in Nova Scotia serves another abhorrent example - while founded by Black refugees in the 1840s, the city of Halifax systematically marginalized the community by utilizing it as a site for urban sewage and dump, subsequently paving the way to its public condemnation as a "health hazard" unworthy of fire and police services, sanitation systems, and basic water services (Kelly, 2017:16).

Such examples of anti-Black racism, as well as the notorious injustices committed against Indigenous populations, are just some of the few ways Canada was already engaged in the exclusion and subjugation of 'non-whiteness' from its making as a nation prior to its first century as a Confederation, when more formalized immigration policies were premised on "explicitly racist principles" (Arat-Koc, 1999a:207). Immigrant selection was based on country of origin and race (Siemiatycki, 2015), upholding racialized categories of 'preferred' and 'undesirable' that were only eradicated in the 1960s in favour of a more 'objective' approach with the points system. At the same time, policy also followed a 'tap-on, tap-off' pattern in which Canada would open its borders when it came to filling labour needs and close them in times of economic downfall (ibid.). Its history of slavery and dispossession, and the inferiority associated with "just being of a darker hue" (Sadlier, 2010:40; as cited in Kelly, 2017:14) leaves a legacy that informs 
Canada's post-Confederation story, in which Canadian immigration, the marginalization of nonwhite bodies and the exploitation of non-white labour remains in an irrefutable relationship that amounts to numerous more inequalities and acts of racism towards a grander scale of non-white immigrants.

The construction of the Canadian Pacific Railway in the late 1800s was a project crucial to securing today's Canadian west as part of the nation, which brought in an estimated 15,000 Chinese labourers due to low supply of domestic labour. This demographic was not only commodified, employed for wages 30 to 50 percent lower than white labourers and considered just as "valuable" as "an agricultural implement" (House of Commons Debates, 1885:1582; cited in Kelley and Trebilcock, 2010:98), they were largely excluded from political and social participation. While the 1885 Chinese Immigration Act restricted the entry of Chinese immigrants by imposing $\$ 50$ 'head taxes,' the Electoral Franchise Act implemented in the same year excluded any Chinese persons in Canada (both naturalized and not) from the federal vote due to their lack of "British instincts, or British feelings or aspirations" (ibid.).

The pattern of exclusionary and tap-on, tap-off immigration continued well into the 1900s, materializing in form of the 1910 Immigration Act which was "used to legally institute the exclusion of Africans and Asians based on the assumption that they were unsuitable for the climate requirements of Canada" (Kelly, 2017:18), but exceptions were made based on the need for cheap labour. For instance, though Caribbean Blacks were refused entry with the utilization of Subsection (g), Section 3 that was premised on "assumption that they will become a public charge," men were none the less being recruited as labourers in maritime ports (Kelly, 2017:2223). Continuing into the world war eras:

...economically recessionary years such as those immediately before and immediately after the First World War were characterized by more selective admission criteria $[\ldots]$ 
economically more prosperous times such as during the war and throughout the mid to late 1920s witnessed a relatively more open immigration policy (Kelley and Trebilcock, 2010:168).

As much as "the need to select the 'right kind' of immigrants, persons who would contribute towards the growth of a great nation, continued to be voiced" (ibid.), the high numbers of 'undesirable' immigrants being admitted just before the First World War as labour as demanded by large entrepreneurs and the operation of the Railway Agreement suggests how economic voices were among the loudest, particularly during times of prosperity. However, when Canada slid into what would be known as the "blackest cloud in Canadian immigration history" (Kelley and Trebilcock, 2010:260) between the Depression in the 1930s and the end of World War II in 1945, discourses on 'preferred' and 'undesirable' races and countries of origin informing considerations of who were "readily assimilable" (Kelley and Trebilcock, 2010:213) once again took explicit forms of reality.

During the Depression, admission requirements as legally coded were the tightest they have ever been in all of Canadian history, exclusive to a very small number of classes composed of white American and British subjects (Kelley and Trebilcock, 2010). Moreover, the federal administration made frequent use of deportation as an "inexpensive and expedient method of clearing from the welfare roles those of foreign birth" (Kelley and Trebilcock, 2010:221). At the dawn of the war, despite economic recovery warranting a 'tap-on' approach, Canada's imminent military involvement gave policymakers 'an out' from relaxing admission requirements. Beyond stated reasons relating to reluctance around the permanence of the economic upswing, the biggest reason "as revealed in the public debates of the period and in internal government documents and memoranda" was to ensure Canada "did not become a haven for the displaced, and mainly Jewish refugees from Nazi aggression" (Kelley and Trebilcock, 2010:257). Canada 
accepted fewer than 5,000 Jewish refugees during the war, the worst record of any democracy (ibid.). Beyond exclusionary admissions, Canada waged war on its own by interning immigrants whose descent is from 'enemy countries.' The most notorious case is that of the Japanese community in which more than 22,000 Japanese immigrants and Japanese-Canadians were forced out of their homes and apart from their businesses, and into internment camps located in the inner regions of British Columbia.

The interests and values of post-war Canada congregated on the mutual consensus that "explicitly racist immigration policies were no longer defensible" (Kelley and Trebilcock, 2010:324). The shift in the policymaking landscape to more "open" and "democratic process[es]" that eventually led to the implementation of the 1976 Immigration Act, and in fact expanded into the 1990s ironically rendered the terrain more conducive to divided opinion (Kelley and Trebilcock, 2010:414). Amidst this "fraying consensus" (380), one tenet that held the most ground was the relationship between expansionary immigration policies and labour market productivity. The introduction and implementation of the points system of immigration in the 1960s thus marked a paradigm shift from explicitly exclusionary to responsive to the 'neutral' needs of the labour market (Arat-Koc, 1999a). However, while seemingly positing immigrant selection on 'objective' human capital factors, "gendered and racialized effects of immigration [continued to] operate in complex, subtle, and sometimes seemingly contradictory ways" (Arat-Koc, 1999a:209). Similarly, Dua (1999) notes how racial inequalities persist through immigration, particular economic immigration, by only admitting "third world immigrants to fill specific gaps in the labour force which could not be filled otherwise" (Law Union of Canada, 1981: 235; citied in ibid.). Basing admission on "economic and social capital of potential immigrants" meant that "immigrants from poorer countries had no chance to 
migrate," (Kelly, 2017:25); yet those who are admitted find their skills and credentials unrecognized by Canadian standards and are thus forced into incommensurate employment, much of which are low-paid. The binary between 'preferred' and 'undesirable' that was supposedly long-gone is simply reproduced with the points system in a more subtle and insidious fashion, merely under the guise of 'objective' criteria.

Throughout shifts in attitudes and values, what persists into today as the pillars of immigration is its economic utilization, a machine for the importation of 'cheap' and 'flexible' labour performed by non-white bodies. Moreover, if "immigration is a central site through which national communities are institutionally imagined and materially constructed" (Vukov, 2003:336; as cited in Kelly, 2017:18), and as history has shown, a tool for the containment of non-whiteness external to Canada's borders and even within and their exclusion from participation and membership rights, it warrants inquiry into how economic immigration today serves the same purposes with programs like the TFWP, the LCP and the PGWP. Only this time, given the shift to 'two-step' immigration, much more individuals are being admitted as legally temporary migrants, a status that entitles them little to no rights nor protection as they are subjected to 'the good' of the very nation that feeds into their exclusion and exploitation.

\section{Structuration theory}

Posited on Giddens' critique of positivism, functionalism and evolutionary analysis in their conviction to the invariance of human organization (Turner, 1986), structuration theory is an understanding of social action and change constituted by interactions between human actors and societal structures. To navigate through the complexities of this framework and extract the elements I employ for this study, I utilize the help of texts by William H. Sewell (1992), Jonathan H. Turner (1986) and Richard L. Wolfel (2005). 


\section{Human agents}

In Giddens' understanding of society, the primary player is the human and their agency. All humans have the "inherent" capacity for agency, for what Sewell (1992) identifies as essentially the capacity for "desiring, forming intentions, and acting creatively" (20); it is "as much a given as the capacity for respiration" (ibid.). Thus, as inherently agents, all humans are "knowledgeable" in that they "know what they are doing and how to do it" (Sewell, 1992:9); as well as why they are doing it, as human action is "intentional or purposeful" (Giddens, 1979:56; cited in Wolfel, 2005). Knowing why is also part of what makes human agents "reflexive"- they are able to "reflexively monitor their own conduct and that of others" (Turner, 1986:973). The ability to monitor action is influenced by two levels of human consciousness. The first is "discursive consciousness," which is "the capacity to 'give reasons' and 'rationalize' conduct"; the second is "practical consciousness," which constitutes "unarticulated knowledge" utilized to "implicitly orient themselves to situations, and to interpret the acts of others" (ibid.). Hence, human action can also be unconsciously motivated, and have unforeseen, or unintentional, consequences, which speaks to the imperfection and the limit of human knowledge (Wolfel, 2005). These unintentional results of human action are deemed just as significant to social relations and change as intended human action (ibid.).

There is large variety in the ways human agents exercise their agency, as well as in the degree and extent of their agency. The differences are highly dependent on the social context in which they are acting, a space that is shaped and informed by particular structures. This bodes true in terms of one's social positionality within a single social context. Agency differs in extent depending on how one is located at intersections of various social positions, including but not limited to gender, class, ethnicity, occupation, sexual orientation, education, and, in the case of 
this study, immigration status. Sewell (1992) posits that different positionalities provide different kinds of "knowledge" and "access to different kinds and amounts of resources," and "hence different possibilities for transformative action" (21). In short:

Structures empower agents differentially, which also implies that they embody the desires, intentions, and knowledge of actors differentially as well. Structures, and the human agencies they endow, are laden with differences in power (ibid.).

Differential access to power are advantages for certain human agents over others, which result in inequalities of power. This is known as the dialectic of control, and has two important elements: the first is the fact that Giddens recognizes all human agents have power; if they have no power, then they "cease to be an agent" (Giddens, 1984:149; cited in Wolfel, 2005:16). Secondly is the dialectical nature of these power imbalances. Resources in a society are constantly changing in nature, " as a group uses a resource, it changes society and, in the same process, changes the resources that can be used in the future because society adapts to the use of the resource" (Wolfel, 2005:16).

\section{Structures}

Structures shape and inform the social context in which humans are acting, implicating on the way they exercise their agency and the extent and degree of that agency in producing action. Structures shape and inform action because they are what humans draw upon to enact their agency. Human action is "structured knowledge" (Sewell, 1992:4) applied. In this view, structures are not merely restraints on agency, but they enable agency in structured ways, as "principles that pattern social practices" (Sewell, 1992: 6).

By Giddens' original definition, structures are constituted by "rules and resources, recursively implicated in the reproduction of social systems" (Giddens, 1984:377; cited in Sewell, 1992:5). In this understanding, humans enact upon the 'rules' and 'resources' that 
constitute structure, while structures themselves are informed by the recursive enactment of rules and resources by human agents. This emphasizes the dialectical character of structure and agency, in which both elements "interact with each other to influence change in society." Before elaborating further, rules and resources will be briefly defined.

Sewell (1992) notes that Giddens implied rules to also be virtual in existence as they are only actualized as action when put to practice by human agents. He thus introduces 'schema' as the more apt descriptor because 'rules' denotes tangible and more formal artifacts of social life such as legal codes and contracts (8). Thus schemas are understood as the 'formulas' for social practices in social systems (Turner, 1986: 972). Alongside schemas are 'resources,' which are "the means by which individual actions are facilitated and constrained" (Goss and Lindquist, 1995:10). Resources are either "allocative" or "authoritative" (Giddens, 1979: 100; cited in Sewell, 1992:9). Allocative resources are straightforwardly material objects (ie. land, means of labour) that "condition differential access to the material world and entail powers of wealth and property" (Goss and Lindquist, 1995:10). Authoritative resources refer to "physical strength, dexterity," "emotional commitments" and "knowledge," (Sewell, 1992:9) that of which "conditions differential access to the social world and political power over other people" (Goss and Lindquist, 1995:10).

Two important characteristics about structures is their multiplicity and their intersections with other structures. The social sphere is an interaction of a vast number of structures that are both similar and different to each other. Thus, structures "may sometimes operate in harmony, but they can also lead to sharply conflicting claims and empowerments" (Sewell, 1992:17). This multiplicity of structures also implies their intersections and overlaps, particular "in both the schema and resource dimensions.” Accordingly, 
Not only can a given array of resources be claimed by different actors embedded in different structural complexes (or differentially claimed by the same actor embedded in different structural complexes), but schemas can be borrowed or appropriated from one structural complex and applied to another (Sewell, 1992:19).

\section{Duality of structures}

Placing everything together, if structures are schemas and resources recursively enacted by human agents in social practices, and they are what human agents draw upon to engage in social practice, then structures can be understood as "both influenced by and influenc[ing] social change" and action (Wolfel, 2005:11). This is known as the duality of structure, recognized as the most significant element of structuration theory in that it offers a foundation upon which to theorize social change over the long-term (Wolfel, 2005; Sewell, 1992). If power comes in numbers, "action may have the consequence of transforming the very structures that gave [agents] the capacity to act" in the first place (Sewell, 1992: 4). In being "both the medium and the outcome of [social] practices," structures are therefore potentially mutable (ibid.).

\section{Temporariness as a manifestation of state power}

Upon the premise that "all social action is shaped by structures" (Sewell, 1992:22), the state can be understood as a type of structure of "low depth" and "high power" (Sewell, 1992:24). The state differs in nature from other structures that are more deep and pervasive ${ }^{12}$ as it exists "near the surface of social life" as "consciously established, maintained, fought over [...] rather than taken for granted as if they were unchangeable features of the world" (Sewell, 1992:24) None the less, the state possesses massive capacity to mobilize power due to its vast arsenal of resources (ibid.). The Canadian state can thus be understood as holding large concentrations of power to control its citizenry and non-citizenry, and how it sets out to control

\footnotetext{
${ }^{12}$ Sewell (1992) talks about language and capitalism as structures with immense depth in that their recursive application and reproduction via daily social practices are almost unconscious and "second nature" (24). He notes, however, that it can be debated that such depth bodes true for some forms of political structures, such as the American constitutional system.
} 
by distributing resources in uneven ways to result in social inequalities and oppression (Sewell, 1992) is informed by its histories of domination through violent dispossession and exclusion. In the context of immigration today, it can be argued that 'temporariness' is a manifestation of state control, the lesser share of distributed resources that subsequently disempowers and excludes its non-citizen and non-permanent populations. As a matrix of systemic oppressions, this dynamic stems from Canada's 'racial story' that has informed migration throughout its history in which "non-white and working-class whites were and continue to be seen as invaders or threats to the nation" (Fobear, 2014:n.p.).

The tangible tools that construct the realities of temporariness include work permit programs such as the LCP, the PGWP and the TFWP, "enforcement[s] of different entry categories and forms of legal residency status" that "create paper borders [...] made up of the various restrictions, limits, and containments regarding people's mobility" (Latham et. al, 2014:7). However, as much as they are unwanted, temporary migrant workers are also wanted. While they are "potential threats" to the racialized nation-space (Latham et. al, 2014:7), in the context of a globalizing and knowledge-based economy Canada is necessitated to let highlyskilled temporary migrants through its borders in order to maintain its edge. This means the securitization of the state's national space must therefore take place within its borders; those who seek permanence must first be contained and 'legitimized' before they can be admitted. As 'temporary workers,' the 'vetting' for their permanence entails the extraction of their labour for the growth of a nation that excludes them for the time being. This contradictory logic parallels the same sentiments that fueled Canada's nation-building efforts throughout history at the expense of those who did not 'fit' into the image of the white, British settler:

Canada's national identity and its regulation of immigration is informed through ongoing settler colonialism in which the erasure of Indigenous persons and the control of non- 
white immigrants go hand-on-hand with the creation of the Canadian state and the solidifying of its borders (ibid.).

Thus, while the state seeks to contain temporariness and 'others' it to permanence and citizenship, it renders it porous because in Canada, "where immigration will soon account for all net population growth" (Gates-Gasse, 2012:272), temporariness via the 'two-step' approach serves the in-house "testing ground for the potential extension of secure legal residency and associated [citizenship] rights" (Rajkumar et. al, 2012:486) to those who can demonstrate in that they can 'successfully integrate.' Integration comes in as a top-down conception, a defined set of markers that allows the state to sustain "hierarchical orderings of power and importance" (Victor, 2007:3) in which international students, as 'ideal immigrants,' make the top of a larger bottom tier that is temporary migrants. Via the demonstration of fluency in French or English, and the possession of skills and a job that are deemed 'relevant' to national growth, access to permanence is granted, the cap of the hierarchy. Those who are still in pursuit, or who eventually fall short, are "temporarily temporary" (Latham et. al, 2014:7), an implied state of "in-betweenness' to which the end result is either permanence, or exclusion due to an 'incapability' to integrate (ibid.). Exclusion manifests as the requirement to leave the country by the permit's expiry date; and in its extremities, as criminalized instances such as orders of deportation or overstayed permits.

With the use of primary data from interviews with former international students pursuing permanent status, the rest of this paper explores how realities of temporariness look like; how state power manifests as regulations that control and contain day-to-day life. Participants are investigated as knowledgeable and reflexive agents who apply "structured knowledge" (Sewell, 1992:4) in their simultaneous adherence and negotiation with state power. 


\section{METHODS}

This study utilizes primary data gathered from five interviews with former international students who have pursued or are currently pursuing permanent residence status in Canada. In this section, I describe the methods used to recruit participants, the design of the data collection, and several ethical considerations. My recruitment strategies and data collection methods were approved by the Ryerson University Ethics Board.

\section{Recruitment criteria}

My intention was to capture the diversity in trajectories of former international students, while at the same time keeping recruitment efforts as uncomplicated as possible. I thus designed recruitment strategies to target three demographics of former international students, taking into account the range of possible experiences that exist in each demographic: those who are currently pursuing permanent status, those who are permanent residents, or those who were unable to acquire PR status and have consequently left Canada. I recruited a total of six participants from the first two demographics. Due to time constraints, I selected five interviews to utilize data for this study: four with participants currently pursuing permanent status, and one who is already a permanent resident.

The recruitment criteria on which the first demographic is based are those who a) have graduated from a postsecondary institution in Canada, b) are currently living in Canada, and c) are pursuing permanent residence (PR) status, which is defined as at least one of the following: has decided to stay in Canada permanently; is preparing to apply for PR; or has submitted applications and are awaiting decisions. This demographic consist of five participants. The second and third demographic were recruited based on the following criteria: a) have also graduated from a postsecondary institution in Canada, and b) are either permanent residents of Canada for at most five years; or not permanent residents of Canada, and due to the inability to 
acquire permanent status, have left Canada sometime in the last five years. I recruited one participant with permanent residence status for the second demographic.

\section{Recruitment strategies}

I utilized multiple recruitment strategies, the first of which involved hanging recruitment posters in high-traffic locations in the downtown area. I posted on community boards in cafes and community libraries around downtown Toronto; and in order to attract attention from current international students, I advertised in various spots around the campuses of major postsecondary institutions. Current international students is a demographic I was not directly targeting, but was hoping can pass on information of the study to eligible candidates in their own networks. I hung two types of posters in each location; one describes criteria for the first demographic, and the second describes criteria for the second and third demographic. All posters include my name and contact information, and invites both expressions of interest from eligible candidates and inquiries about the study in general. Unfortunately, no participants were yielded from this strategy.

All participants were recruited via my second recruitment strategy, in which I utilized my own networks. My networks consist of personal and professional acquaintances such as friends, past classmates, and past colleagues; they include current international students, former international students, and those who know of former international students - a mixture of eligible participants, as well as individuals who are not eligible but who may have ties to those who are eligible. Using my own social connections as a starting point, my primary intention was to get individuals in my immediate networks not to participate, but to activate their own networks. 
This use of social networks to recruit participants is a technique called snowball sampling, in which subjects of a study refer the researcher to other possible participants, making the sample group "grow like a rolling snowball" (Cohen and Arieli, 2011:424). As a former international student, it is justified that the sampling 'snowball' starts with myself and 'grows' as my own networks pass word of the study through their networks and so on, to eventually reach eligible participants. In addition, given the limited timeframe for the production of this study, this technique is helpful in its efficiency to "locate the appropriate population with a minimum amount of time, money and effort" (Cohen and Arieli, 2011:428).

I received emails from interested participants, to whom I responded with a copy of the consent agreement. I asked potential participants to review the terms of their participation and to email me back with a second confirmation of their interest. Not all participants replied with a second confirmation, and my correspondence with such individuals ceased. For those who did reply, the dates and times of their interviews were consequently arranged. Most participants signed the consent form in-person at the time of their interview, after I had verbally reviewed the terms of their participation and addressed their questions or concerns. Participants with whom I conducted Skype interviews were asked to review the consent form and ask questions before they signed and scanned the form back to me.

\section{Data collection}

Each participant was interviewed using a semi-structured format. Galletta (2013) sees opportunities in the semi-structured interview "for a narrative to unfold, while also including questions informed by theory" (2). This format aptly complements one of the purposes of this study to portray lived realities in Canada, as narrated by the participants themselves. At the same time, the selected theory of structuration offers a framework to interpret these realities as shaped 
by contextual structures, in this case being participants' legal statuses as temporary residents and the immigration system that defines their pursuit for permanence in Canada.

The semi-structured interview also gives a certain epistemic value to this study. In being "sufficiently structured to address specific dimensions of [the] research question, while also leaving space for study participants to offer new meanings to the topic of study" (Galetta and Cross, 2013:1-2), the semi-structured interview encourages participants to take the lead in sharing their story. As the primary researcher, this format allows me to preserve participants' voices in the narration of their experiences to promote the authenticity of the data. The semistructured format also encourages participants to use this study as a platform to bring up what they feel are significant to their experience, promoting those personal moments as possible areas for further research and thus achieving the other purpose of this study to contribute further into existing literature.

Interview questions ${ }^{13}$ were broad rather than specific, designed to initially prompt participants and give them a starting point. All participants took the liberty in taking the questions to directions most natural to them; and they were expressive and descriptive in their narration of their story. Unscripted probes came about when I wished to further explore a specific area, all the while taking great care to not compromise the authenticity of the narrative with my own interpretations. For instance, I requested participants to explain why they felt a certain way, why they chose a specific descriptor to characterize a certain moment in their experience, or I would 'check' my immediate thoughts with the participants by asking if I had understood correctly what they had said. Finally, towards the end of the interview, I inquired if the participant wished to add anything else beyond the questions I had asked them, to which most had a response.

${ }^{13}$ Please see the Appendix for the interview guide and lists of sample probes. 
All interviews were audio-recorded with two recording devices. Besides the interview itself, I collected the following demographic data of each participant: age, country of origin, educational level, province/territory of study, province/territory of residence, occupation or job title (no specifics such as place of employment were asked), immigration status, and length of time the participant was present in Canada. Each interview was roughly an hour and a half, or an hour and forty-five minutes in length, and were transcribed by myself. Participants had the option of reviewing their interview transcript to ensure they were comfortable with their responses, and were entitled to request edits and redactions.

\section{Ethical considerations}

Because of its use of social connections and existing relationships, which may include acquaintances, friendships and even family ties, snowball sampling poses the ethical risk of undue pressure or feelings of obligation to participate. To mitigate this risk, I strictly employed an email-only line of correspondence. I sent one email per recipient and requested all participants, in both my immediate networks and external, to express their interest via email only. Further, the email explicitly states that the recipient is being contacted not to participate as an interviewee, but for their voluntary assistance in passing on the study to their networks.

All participants were ensured strict anonymity and confidentiality. Pseudonyms were used in the transcribing of the recordings, as well as in the published results. Recordings of the interviews were deleted off the devices within the same day of the interview, after being transferred to my personal computer. Transcripts did not contain the name of the participant, and potentially revealing information such as names of schools, workplaces, and specific dates were redacted. Participants' real names, contact information, and demographic data were stored electronically as three separate documents. 
Any hard copies that were produced, including written notes taken during the interviews, were shredded and disposed following the submission of this MRP. Email correspondence between myself and each participant were deleted as well following the submission of this MRP. The original audio-recordings and their transcripts, as well as participant information, all of which are electronically stored, will be cleared, deleted and destroyed in five years following the submission of this MRP, as I have intentions to publish for a journal or use this research for further academic work.

Besides anonymity and confidentiality, the ongoing voluntary nature of participants' consent was also maintained. As stated on the consent form and as a verbal reminder during the actual interview, participants were informed that they could withdraw completely for the study anytime during the interview, and up to twenty days after the interview. The reason for the twenty-day window is the short timeline of this study; to ensure that withdrawals do not compromise the completion of this study by its assigned deadline. During the interview, participants had the right to pause at any time for a break, request I turn off the recorders or cease note-taking. They had the right to skip questions and to refuse to disclose any information they were not comfortable sharing, including their demographic data. 


\section{FINDINGS AND ANALYSIS}

In this section, using the framework of structuration I analyze primary data extracted from interviews to explore participants' pursuit for permanent residency (PR) as a complex flux between structure and individual agency. I start with a demographical summary of the participants themselves, and preface how participants came to decide upon permanent residence in Canada, as context to each participants' trajectories. I then move on to highlight various ways the regulatory power of Canada's economic immigration apparatus manifest in participants' realities. Participants are framed as knowledgeable and reflexive agents in how they enact their agency in adherence to and negotiation with the structure's regulatory power, as well as in their reflections of Canada's immigration system.

\section{Demographical summary of participants}

To illustrate various trajectories to permanent residency, this study utilizes the interview data of five participants. At the time of their interviews, participants were at different points in their trajectory, summarized in Figure 5.1 below. Accordingly, three participants have all submitted applications for permanent residence and are waiting for a decision. These participants are either on implied status ${ }^{14}$ or bridging open work permits ${ }^{15}$. One participant is already a permanent resident and another is on a Post-Graduation Work Permit (PGWP) and actively putting together an application to submit. Participants are either in their mid-to-late 20s or early 30s, with the biggest concentration in the mid-to-late 20s bracket. Most participants reportedly arrived in Canada between the ages of 18 and 20. The length of time participants were present in Canada, from the day they arrived as students, were within a close range of 7 to 8 years. Two

\footnotetext{
${ }^{14}$ Implied status is authorization to remain in the country and continue working as per the terms of their permit beyond its expiration, while one's application for permanent residence is being processed. Implied status ends when a decision is reached.

${ }^{15} \mathrm{~A}$ bridging open work permit is granted to an individual whose application is under review to allow them to continue working until a decision is reached.
} 
participants completed postsecondary education in Ontario, two in Atlantic Canada and one in British Columbia. All participants are current residents in Canada; one resides in British Columbia while the rest are in Ontario.

There is large variation in terms of participants' fields of study, fields of employment, and countries of origin. Two participants graduated from programs in the social sciences, one from media studies, one from social work, and one from the applied natural sciences. With the exception of one participant who is pursuing graduate studies, participants are currently employed in insurance, social work, student services, and career development services. Finally, prior to Canada participants came from the following countries: Japan, India, Ghana, Morocco, and Indonesia.

Figure 5.1-Participants' trajectories and current immigration statuses

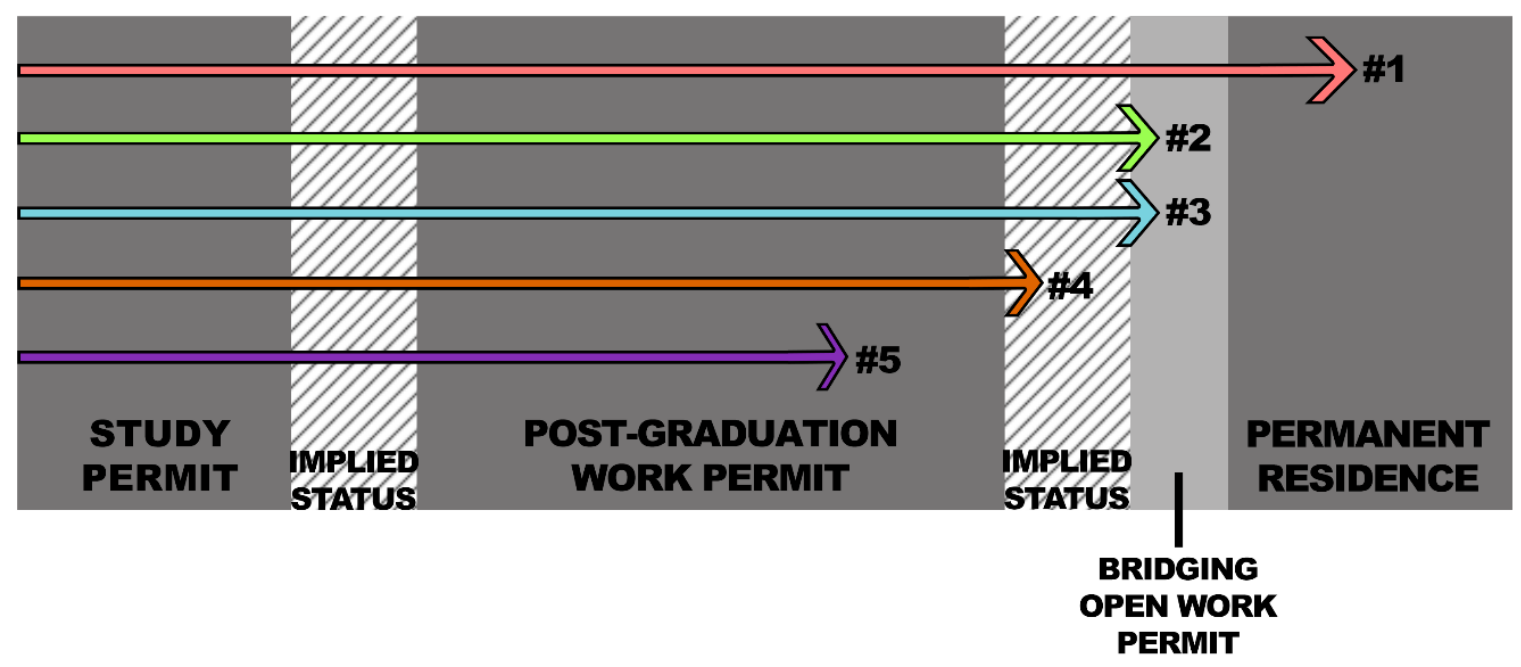

Prefaces to permanent residence

Before examining the trajectories themselves, it is significant to capture their starting points: how and why participants came about to the initial decision to pursue permanent residence. Across all narratives, I categorized the prefaces to their trajectories as either 'deciding to study in Canada,' or 'deciding to permanently stay in Canada.' For some participants, the 
decision to study in Canada was more or less appended with the consideration to pursue

permanent residence after graduation. For others, the decision to pursue permanent residence was blatantly separate from that to study in Canada - the former came after the latter. In separating the different layers constituting participant motivations and decision-making processes, some instances proved more elaborate than others, illustrating the complexities that make up the decision-making processes alone.

\section{Deciding to study in Canada}

Requesting participants to think back to the time they first made the decision to pursue permanent residence yielded a large variety of responses. Some of these responses constituted the decision to study in Canada. Among these responses, Participant \#1 was the only one who identified this decision as essentially one in the same with that of studying in Canada. $\mathrm{He}$ completed the first half of his studies in Europe, and decided to finish them off in Canada when he heard about the permanent residence opportunity:

I knew [Canada] was one of the few countries that allowed people to come, whether as students or as temporary workers, to eventually apply for permanent residency. I had some friends who came here before and they told me about Canada. They told me about the system, that if you come here and you study and you get your things done in a correct way, there are higher chances that you can stay here in a permanent way. So I was encouraged by them to come to Canada. This was a huge factor in my decision to come to Canada, the fact that there is a possibility to be granted, like, a permanent status here.

With other participants, I found that studying and settling permanently in Canada were decisions that were not one and the same, but closely overlapped. Participant \#4 had the 'idea' she wanted to attain permanent residence prior to arriving as a student, but this was an idea influenced by the fact her brother and two sisters who were already in Canada as permanent residents and citizens:

[I had the idea I wanted to stay] just because all my siblings did. And I figured, you know, my parents sent me off to school here, just to give a better opportunity to us all and 
give us a better life. So yeah, I already had the idea that I [would] most likely stay in Canada if I moved here.

Unlike Participant \#1, the prospect of permanent residence per se was not a clearly defined reason to study in Canada. Studying in Canada "just made sense because in terms of tuition, it cost the least" compared to other options she was looking into in the United States, the United Kingdom, and Australia; and the fact that she already had family in the country.

Participant \#4 mentioned that moving cities, an event that occurred after she graduated, "fortified [her] decision to stay here.” Hence, she went from an 'idea' to a more solid decision over the course of a few years, when she grew to "like it here" and "felt like there was a lot more opportunity here," on top of having been here for "a long while":

I do like Canada, I built a life for myself here. I've led all my early adulthood here, I came here when I was 18. I'm going on to [late 20s] now, it's been a long while. I've gotten used to Canada, to the way things are here.

In addition, there was also the desire to be able to choose between staying and leaving, to which she connoted permanent residence (PR) as the means.

...my main reason for applying for PR wasn't just to stay in Canada, it [was] to give me the option. Because I might decide to go home at some point, just kind of depending on how things go here. But at least if I have my PR [...] then it's like I know I found my grounding in Canada, or I can go back home if I like; as opposed to being booted out the country and having to stay in Ghana.

In the case of Participant \#5, she knew from her very first day in Canada that she wanted to stay permanently. She contextualized this decision to her life prior to arriving and the events leading up to choosing Canada as her destination of study:

I came out as gay when I was 15 [and realized] that maybe back home was not the safest place for me. So then I started my online research and I learned back then that Canada just legalized same-sex marriage [...] A couple of months after this process, my mother and I went to an international education expo [and came across a booth with a picturesque backdrop]. [So], the combination of [this] beautiful, TV picture of [Canada], a very kind international student advisor guy, my love for [field of study], and also the factor of like, "oh yeah Canada, it's a safe place for gay people, I heard!" 
Once arriving, she experienced immediate sense of belonging she rarely encountered in her country of origin, solidifying her determination to stay:

Before I came to Canada, I have always felt like a stranger in my own country, at least in my own city. I felt like the way I lived my life in general, my outlook in life, my values, are so different. I was such an alien there. My first day in [Canada], I don't know what happened. I can still remember the feelings to this day. It felt like home.

Participant \#5 was thus very attached to the idea of staying in Canada, but recalled not "really understand[ing] the concept of permanent residency." She was forced to leave upon the expiration of her study permit, and several years later she returned to Canada on her second study permit and attended a postsecondary institution in a different field of study. While she already had a very strong commitment to stay permanently, a newfound passion in her studies and an increasing feeling of "self-worth" strengthened it further:

I grew up thinking I wasn't good in anything. The scale of your intelligence was measured by your ability in math and hard sciences, where I came from. The fact that I got to learn a lot of things from [fields of study], and feeling, "oh, I'm actually good at this, I actually understand these things! Maybe I am worth it, maybe I do have something to offer!" That event, that slow process [and realizing] I can give [back] to my communities using my frameworks and approaches, that [all] became synonymous to Canada. It was here where I slowly started to build my self-worth.

Like Participant \#1, Participant \#4 would set quite the strict parameters in her planning process, in which the aforementioned factor of safety, as well as a newfound passion in her field of studies, would grow incrementally over time as motivations to stay.

\section{Deciding to permanently stay in Canada}

For Participant \#2 and Participant \#3, the permanent residence opportunity was not at all part of the reasons why Canada was chosen as the destination of study. In citing quality of education, quality of life, and cheaper tuition fees, the decision to pursue permanent residence for these participants was not the same as the decision to come to Canada to study; rather, the 
former occurred after the latter. Both participants described elaborate processes similar to Participant \#4 and Participant \#5 in which the 'idea' or the 'want' to remain in Canada strengthened and solidified into a plan in the course of several years, and by several factors. Participant \#3 knew he wanted to be a permanent resident far before he graduated, yet he recognized the decision to pursue permanent residency and the process of getting to that point were different:

I think deciding to be a PR and doing things to help you get there are different things. I probably decided I wanted to be a PR a year into me coming here [to Canada]. I knew I wanted to stay here, given a choice. But I think I only got serious about it after I graduated university.

While "life worked out" for Participant \#3 after graduation that set a path in motion towards permanent residence, it was finding his partner that solidified his commitment to the pursuit:

[Permanent residence] [may] always at the back of someone's mind, but not many people would actively make big decisions in their lives to go down that path [during school]. So you graduate university, and even though you knew that to [get] PR you needed to have a certain job [...] people just got the job that they could, because it's tough to get a job when you graduate. And that's what I did. [PR] was at the back of my mind. Then I fell in love after a while and it came to the forefront. I said, "I've got to do everything that I can to stay here."

Participant \#2 was "not think about immigration at all" when applying for schools in

Canada and well into her years of studies, as it was just all about "go[ing] to class, do[ing] assignments," and "rest[ing] over the summer." The decision to pursue permanent residency came only after the decision to stay in Canada to work after graduation, which entailed she secured a PGWP:

...it felt like a chance - that work permit, not permanent residency but that work permit was an opportunity that was put right in front of me, and so [...] I decided to apply for it. At the point, I didn't have anything lined up back home, so I thought, "well, might as well try something out here" $[\ldots]$ once I applied for that, I started to think about where this could take me after. 
Leading up to the PGWP, Participant \#2 expressed that in the years prior she was 'putting off' making plans, though it was "a lingering thought." She attributed it to the burden of having to "balance school, work, and then [trying to figure out] life after university." Her final year of school comprised what she describes as "long term thinking," an elaborate process in which she "thought about all different options" considering what she would do if she returned to her home country or if she stayed. She knew, however, that her goal was to attain higher education, and she was "trying to find ways to get there":

I got really good advice from my dad, actually. He said to first make a 5-year plan and then a 10-year plan, then just work back from that point [...] so I kind of looked at 5 years from the time I was thinking about what I wanted to do [...] that included, what if I went back home, then I would have to apply for another study permit to go back to school; and then that incurs international student fees - what would that mean, how would I feel after the fact? [...] then there was the stream of thought: if I stayed in Canada, I could apply for this new Post-Graduation Work Permit [...] then I would really have to just go for the PR option so that I can be a Canadian student when I go back to school.

\section{Trajectories to permanence as regulated realities}

Structural control manifests as temporariness that constrain the space within which participants act in their pursuit for permanent residency, the hypothetical 'testing ground' in between temporary status and permanence in Canada. Below, various moments from participants' experiences on this 'testing ground,' and reflections thereof, are extracted and analyzed as regulated realities of temporariness. Based on participant responses, I conceptualize forms of regulations that enforce this temporariness as time limits, the specificity of employment, and their ascribed legal status as temporary migrants, which has both material and subjective manifestations. 


\section{Time limits}

Time was a factor all participants were constantly aware of. Study permits have an expiry date, appended with a 90-day window international students are given from the date of their graduation to either change their status by applying for a PGWP, or leave the country. Participant \#5 was forced to confront the latter when her first study permit expired, and the private institution she attended did not qualify her for a PGWP. She described this experience as an urgent pursuit to stay through any means necessary:

I still remember the last few months when I realized, "holy s--t, my time here is about to end!" So I was really trying to find a way to stay [...] those last few months, oh my god, I was running around trying to find a way to get a student visa extension by applying for a different program but my mom did not have enough money back then; or find a way to seek an employer - if an employer can sponsor me [...] I went to different institutions to see their international student advisors and admissions officers, to see if there was any way I could get a scholarship or whatever, to continue my studies, taking whatever, just for me to stay. I wasn't successful, and I had to go home.

Similarly, PGWPs also have expiry dates, and unless permit-holders have submitted an application for permanent residence (which grants them implied status or qualifies them to apply for a bridging open work permit), they would have to leave the country. The maximum time a PGWP grants is three years, which all participants were given as graduates of two-to-four year programs. On top of restrictions of time, PGWPs are also not renewable. Permits are not extended if more time is needed, even if employed; and they are not granted again following a second study permit.

Time was a pronounced constraint particularly in the trajectories of Participant \#2 and Participant \#4, starting with their last-minute applications for their PGWPs as a means to stay for the time being. Implemented just before her graduation, Participant \#2 applied for the permit just within the 90-day window, a decision in-the-making since her final semester: 
I started to think about it probably, like, second half of my last year of university; and I started to panic, kind of like, "what am I going to do, time is running out," kind of feeling.

While still uncertain about pursuing permanent residence, she expressed how she could not just "go back home and think about what to do"; she saw the PGWP as an "opportunity put right in front of [her]" and subsequently applied.

Despite not having "any kind of plan," Participant \#4 was certain that missing the opportunity to stay longer in Canada via the PGWP would leave her in a state of "limbo":

...when I applied for my PGWP I was so worried because I was just like, "what if I don't get this permit, then I have to go back to Ghana, what am I doing?" And I was a little late on my application too because I just kind of lost track of time. I didn't realize how long it would take and all of that [...] it [was] frustrating because at that point I was like, "okay, now I'm really in limbo if I don't get this, I have to leave right away."

Participant \#4 then later fell in a state of 'confinement' midway through her work permit, when she delved into the technicalities of the application. Though she had accumulated the hours needed to apply, she realized that if given the opportunity she could not quit her current part-time job for work that was full-time, as the hours would not "rack up by the time [her] permit expires":

I was under a bit of a time crunch when I was applying because it took me a while to rack up those hours. At this point I couldn't switch jobs because it's like, I've been here for a year and a half, and I have a year and a half left on my permit. Even if I was to find a full-time job now, the number of hours wouldn't be rack up by the time my [permit] expires. So applying for this PR has kept me in one place, you know [...] let's say you find a job, you're in it for a while and you hate it. You can't quit at this point [...] I find that [the application] kind of keeps you confined, in some degree [...] it just doesn't give you much wiggle room, at all, I feel, like the whole process in general.

Time was still not on her side when she finally created her Express Entry profile and saw that her score was not as high as the cut-off average.

I saw my points, and I remember I was so upset. I was crying [...] I was like, "they're going to kick me out of the country!" [...] but at the end of the day you just leave [your 
application] in the pool there while your visa's ticking and just hope for the best, right. So that's all I could do, play the waiting game.

At this point, Participant \#4 had only about 6 to 7 months to 'wait,' until the recent changes to Express Entry gave her score a boost, resulting in an ITA in her inbox a few weeks later. Along with these changes was an extension of the window given to submit an application, from 60 to 90 days. This also was the case for Participant \#2, who upon applying for Express Entry did not attain a score that reached the average cut-off, but received a similar boost in points thanks to the policy changes. Leading up to her application, Participant \#2 owed it to the ample time she had left on her permit, which she described as a "lifesaver feeling," for allowing her to give permanent residence another shot after two unsuccessful attempts at PNP.

While time seemed to shift to the advantage of Participant \#2 and Participant \#4 later into their trajectories, the advantage was granted by the structure, illustrating how time is a resource controlled by the state, by extension a mechanism that can be manipulated in order to alter the parameters of the space in which participants operate. Temporal limitations are discursively imposed concepts of time "that [are] both linear and extremely short" (Victor, 2007:3), necessitating former international students to "prove their abilities to integrate into the Canadian labour market within their limited time as temporary migrants" (Roach, 2011:16). Participant \#5's experience of 'trying to find ways to stay,' Participant \#4's feelings of 'confinement' in her job and the 'life-saving' amount of time left on Participant \#2's permit speak to the structure's power in fixing participants in a certain position or empowering them to move forward.

\section{Specificity of employment}

As seekers of permanent status, all participants were tied to finding 'skilled' work. This qualifier for permanent residence stems from the neoliberal character of the immigration apparatus that, in the context of a knowledge-oriented global economy, ascribes worth and value 
to certain jobs over others. In addition, it translates into a sense of hierarchy and exclusion, an understanding of economic immigration as the "commodification of immigrants" (Arat-Koc, 1999a:209):

One of the implications of this commodification is that it leads to an evaluation of people's potential contribution to and value for Canada solely on the basis of their expected place in the labour market. Those people whose skills are considered useless, less useful, or irrelevant to the labour market are either totally excluded from or get differential treatment in immigration (ibid.).

While there is no data to derive from actual experiences that reflect defeated efforts as all participants eventually secured eligible jobs in good timing that allowed them to build a least a year's worth of hours (another requirement for permanent residence), some participants drew upon reflections of their experiences to describe this requirement as 'unfair.' For Participant \#2, it paints a false picture of permanent residency opportunities for international students in Canada, and paralleling Arat-Koc's argument, 'commodifies' international students as valuable based solely on their labour market outcomes:

...I would say stop rubbing onto us the promise that international students are the best candidates for permanent residency because that makes us think it is $100 \%$ guaranteed [for us]. It does not happen that way. It only gives us false hope that that's actually going to happen. [...] I know about Canadian society because I've actually lived here for some time. But I think using that to say, like, "apply!" and make it sound like it's all going to be okay, without saying there are qualifying jobs, you have to have one-year's worth of work experience, you have to have made this much money-without saying all of that criteria, I don't think that's really fair. It just makes you feel, like-I don't know, like it's a false thing.

For Participant \#3, the unfairness boils down to the idea that required "somebody to stay here, not even be a citizen [but] just to stay here" to "have a certain kind of job." He insinuates how this requirement goes against the image that Canada projects as a symbol of equality:

Canada very proudly sort of says, "we are the beacons of human expression, sexual expression, gender equality." Give people the taste of that! And what does that mean? Well, when you graduate university, instead of stressing over how you can stay, stress about where you would be happiest working. But giving them a PGWP for three years, 
which by the way, is generous, I'll give them that [...] but it's three years with a string attached, and that string is [that] you have to find a job that means something [...] I didn't realize that Canada was the kind of country that passed a judgment on what kind of work you do. I think that's kind of strange as well for a country that prides itself on treating everybody equally [...] and this actually goes back to the reason why I came to Canada. I wanted my rights protected. And I chose a country where, at that time, I thought my rights were. By the time I finished [school], my rights are protected, but my ability to stay is not.

\section{Temporary legal status}

Legally speaking, international students and those who have transitioned onto PGWPs are temporary residents in Canada. Temporary legal status is ascribed legal and social subordination - in spite of their physical presence in Canada and their contribution to national economic productivity via tuition payments, day-to-day investments, and employment during school and after, they remain disenfranchised from the same rights and resources as permanent residents and citizens. In addition, studies discussed how temporary legal status (or the lack of permanent status or citizenship) is a factor that creates reluctance on the part of many employers from hiring current and former international students. While the reluctance of employers was not a challenge experienced by any participant, there were cases in which participants were unable to access opportunities otherwise made available to permanent residents or citizens.

As a student, Participant \#1 sought help from on-campus services in terms of career development, and found that the school's career services department deemed him ineligible to receive services:

I went to the school's career services, and I was surprised to find out that [they] only provide help to domestic students, not to international students. International students don't have a specific person who sits with them and [is] like, "okay, this is the labour market, this is how we're going to start your search for jobs" [...] So basically what they did - they didn't really help me, they just wrote their careers website and another generic careers website on a piece of paper and told me, "you can just go and look on your own" $[\ldots]$ technically they should offer help to all categories of students $[\ldots]$ this is the time when I faced a sort of exclusion based on my status. 
It is unclear if it was part of the school's policy that international students were ineligible for on-campus career support. None the less, Participant \#1 mentioned that he went at multiple times "to see if the response was from only one person," but was told the same every time. All in all, there was no counselling available to him to help draft potential career paths as per his field of studies; and the international student centre only offered services limited to immigration issues such as extensions of study permits and work permit applications. This is in line with studies that document gaps in service provisions to international students catering their long-term integration, both during their studies and after.

A second instance of exclusion regards Participant \#4's ineligibity for an internship she came across prior to securing her current job. This too is in line with literature highlighting the ineligibility of temporary status individuals to opportunities enjoyed by citizens and permanent residents:

There was actually another internship at [employer], but I wasn't eligible to apply for that because that job was for Canadians. So some jobs, like, have a requirement because they're funded by the Canadian government, I think. I don't think [my job] is funded by the Canadian government, but some jobs [...] I think there is a stipulation that says the candidate must be a citizen or a permanent resident. So then I wasn't able to tap into those opportunities.

However, beyond tangible barriers to resources and opportunities, what strongly emanated from a number of participants' responses were certain subjective states of being that seemed to root from the fact they were 'not permanent' in Canada

One instance of 'being afforded' recognition lies in the literal requirements of the application process. This was particularly pronounced in Participant \#4's experience, in which her initial Express Entry score caused her a lot of worry as it was not as high as the cut-off average. She expressed this made her feel like her self-worth was being quantified and judged: 
...it's just like they're scoring your self-worth on a scale, based on their own criteria, whatever they see fit [...] you see this s--t, and it just makes you feel like I'm not good enough. The Canadian government does not think I'm good enough; what I'm doing doesn't contribute enough to society.

Participant \#2 recalled her "hardest times" being when she tried to apply through the PNP program twice, and was unsuccessful both times due to technical errors on her end: missing the 45-day window to apply by three days the first time, and accidentally forgetting a page in her passport photocopy. She described it as "two stabs" into her, and was subjected to a period of "self-blame" during a trip home to visit family:

...I was really sad at that period because, yeah, I wasn't able to go back home and tell my family, "look, I did this and I think this is gonna happen" [...] I had to say, "I did this and it wasn't processed." [...] Those feelings, I can't even-I don't even know how I felt. I think it was just a mixture of like [pause] self-blame, and like, "why didn't I check it? Why didn't I just get on top of it right away?"

These feelings of inadequacy and self-blame speak to how temporariness manufactures participants into 'ideal immigrants' not just materially, via their human capital, but also subjectively, pushing the onus to be 'self-sufficient' despite constraints in their material realities; as their self-validation is founded on validation of them by the state. Eventually securing permanence in adherence to rules set by the state in turn validates the state, because it was achieved on the terms of the state. Alternatively, the failure to do so is also a victory for the state as her failure is attributed to her lack of 'self-sufficiency.' This ultimately facilitates the state's re-categorization of her from 'temporarily temporary' to 'incapable of integrating'; or in other words, from a potential 'ideal immigrant' to an immigrant that is 'un-preferred'.

There is also the unwanted prospect of having to go back. For Participant \#5, she spoke of her commitment, or "need' to stay permanently as a "looming, dark cloud" that has "haunted" her ever since her days as a student; insofar as to make her "so scared" from quitting her job despite the high levels of stress and lack of support from her supervisor. She describes how this 
'cloud' intensified over time due to heightened dangers back home due to increasing religious

fundamentalism. Having been attacked once during her time as politically active back home, she fears the prospect of having to return:

There isn't one day when I don't think about my immigration [...] Back home is getting really conservative, and that's scary. It's scary for me [...] it's quite different from some people who might say, "I like it here, it's a great country, I can work here and earn more money," but for me, it's becoming a question of safety [...] I know myself, and if I ever have to leave, I would probably be politically active, which is not safe [...] That dark cloud is like a mix of, "I want to stay here!" and also, "oh my god, I want to be safe, I don't want to die!"

Given the above, Participant \#5 expressed being "so upset" when she and her partner sat down with her immigration consultant, who informed her that due to the part-time nature of her job she would not qualify for the PNP. The situation changed immediately thereafter, when her consultant suggested she and her partner consider becoming common-law partners and pursue Spousal Sponsorship route. Participant \#5 stated that she "knew [spousal] could've been an option" a year or two into their relationship, but remained tentative because having arrived to Canada on her own and having "gone through it all," she wanted to "do this on [her] own." She and her partner are pursuing the spousal option with confidence as "work[ing] together a lot with [her] partner" is more secure and trustworthy collaboration than that with her employer. Yet she sometimes reflects upon another set of power dynamics within the relationship, and how it sustains the aforementioned immigration "cloud":

My partner's white, I'm not; and I always struggle with that [...] You know, a Canadian person sponsoring a brown person, and we talk about it openly. We're working with that struggle. But there's always those pros and cons [...] Whenever we fight, to be honest, I always think about, "holy s--t, what if this fight ends up in us breaking up?" That means that, you know, my immigration goes out the window. So the cloud is still there, it's a different kind of cloud [though] [...] Now I'm realizing it as we're talking, at least my partner and I can fight and still discuss it together. Can you imagine with my employer, like discussing power struggles and labour rights? [laughs] 
Participant \#2 expressed similarly regarding her eventual decision to hire a consultant to help her with her Express Entry application, following her two unsuccessful PNP applications:

I actually kind of had a personal ego feeling, like, "I can do this on my own. No one needs to help me." That's why I tried [immigration] even twice by myself, but I think there's a moment of self-reflection and self-growth in knowing that it doesn't hurt to get help, basically [...] yeah, I don't know, I think [it was from having done] feminist research methods, like, "women can do anything on their own!" And like, "I'm a woman! I can do this!" kind of feeling.

These admissions by Participant \#2 and Participant \#5 can be understood in three interrelated ways. Firstly, 'temporary' is not just a legal ascription, but a lived reality constructed by and forced upon them by their legal status. Second, this is a reality in which both participants do not intend to stay but to move from in order to achieve 'permanence.' Finally, 'permanence' is in the hands of the immigration apparatus of the state, the ultimate structural constraint to their trajectories, to which they attempt to negotiate with their own agency by 'going through' their imposed realities 'by themselves.'

Moreover, Participant \#2 and Participant \#5 both imply how they live in constructed and imposed realities other than that ascribed by their legal status as temporary residents: that of her gender, for Participant \#2; and that of her race, for Participant \#5. As per the multiplicity of structures, structures of inequality work with that of temporariness to encase both participants in a multifaceted space. However, the multiplicity of structures also imply their intersection with other structures (Sewell, 1992), which means participants, as knowledgeable actors, are made aware of the different schemas that constitute each structure, and can therefore orient their agency to challenge them all simultaneously. To 'do it on their own' is a proclamation to overcome multiple structures that constrain their agency; but this is not to say to do otherwise is their agency constrained. In fact, in deciding to hire a consultant Participant \#2 reclaims the notion of 'help' from being a 'gendered weakness' to a positive moment of 'self-growth'; and 
Participant \#5 and her partner are constantly ensuring they stay proactive subjects in their relationship as an interracial, cross-national couple.

\section{Trajectories to permanence as negotiated realities}

I have identified time limits, the specificity of employment, and temporary legal status in its material and subjective forms as enforcements of temporariness and how they regulate participant realities in their pursuit to permanent status. This section re-frames participant realities as products of agency negotiated with regulations, drawing upon instances in which participants, acting as knowledgeable and reflexive agents, confront moments of constraint with creative reflections and enactments of their individual capacities.

Regulations of temporariness in some cases prove quite constraining more than enabling, and are ultimately so as participants must seek permanent status by acting within the structures

of the state. They act within the imposed time limits, adhere to finding skilled employment, and they do not venture beyond the parameters of their legal status as temporary migrants. However, they persevere to position themselves as in control of their daily realities negotiating 'what they want' with 'what they have to do.' Employment in skilled work proved the most demanding enforcement of temporariness, with which participants negotiated the most in the following ways: strategies of seeking and securing skilled employment, balancing pursuits with the need for income, and re-framing mindsets.

\section{Employment strategies}

The primary nature of participants' courses of action entailed their capacity to generate strategies for seeking and securing qualified employment by drawing upon their arsenal of resources, which were mostly professional relationships, and enacting upon schemas from other social contexts. 
For Participant \#5 and Participant \#2, seeking qualified employment entailed being 'selective.' Following the acquisition of her PGWP, the goals of securing employment and "trying to get PR" convoluted in that she was "very picky" in her search for jobs:

Every time I applied for a job, it's like, "I hope this meets the criteria of the Express Entry program.” So I don't think I applied for many jobs. I applied for, like [pause] maybe three jobs before I stayed on at my university as a program assistant.

Participant \#2 spoke of the close relationships she developed during her time as a program assistant, which lead her manager to inform her of a similar opportunity she eventually secured and continues to hold today.

Similarly, having known from day one that she wanted to stay permanently, Participant \#5 evaluated the benefit of "every single job" and connection to her chances for permanent residence, starting from her years as a student:

[...] every single time I would always think about, "okay, how do I become a good enough worker so I can stay?" Maybe they can offer me a permanent job, you know, so that I can stay here using this job. Then I also started becoming involved with the provincial [political party] [...] building relationships with different MLAs, being involved on the federal level, building relationships with different MPs and stuff like that. Always, at the back of my mind, [I was] always thinking, "okay, how would these connections help me in my immigration? Can I get a job from them?"

While staying strategic, Participant \#5 built a personal arsenal of resources she was able to mobilize into employment by involving herself in various activities during her studies, and creating a lot of "meaningful relationships" with "truly a mix of different people." In retrospect, she emphasized the importance of 'meaningful connections' beyond networks, because while "networks can just forget you like that," "real relationships [...] give you jobs." Just before graduation, she received her "lucky" break when she was offered a job in her field of studies. In contrast, Participant \#1 attributed the series of unsuccessful job pursuits following graduation to his lack of social connections: 
...the referral system is very important and crucial in the labour market, which means if you have someone that works within a company and has a weight, an influential [...] a say in that company, they definitely can refer friends; and if you are referred, you have a higher chance of getting into any kind of job. So I understood with time that it was a matter of social networking and the amount of social networks that you had.

These responses align with the literature that finds that international students who were exposed to a greater scope of networks and social connections had a better chance of finding employment in their years following graduation.

While some participants landed qualifying employment due to relationships and adopting a selective approach in their job search, Participant \#1 and Participant \#3 took it upon themselves to qualify their jobs. These strategies entailed a good standing with their employer, in which the transposition of their professional skillset and work ethic granted additional leverage to request a modification of their job description, in writing or in practice, to qualify their positions for permanent residence.

Immediately after securing full-time work, Participant \#1 noticed that the job description "was written in a way that [anyone] reading it may think it was a customer service job."

Customer service jobs are ineligible for permanent residence, and he feared that this technicality could put his chances for permanent residence at risk. He decided to simply "focus on the job itself” and "to get better with [it]" by “master[ing] [its] tasks." In about three months' time, by performing exceedingly well and receiving the recognition of higher management, he secured himself in a situation in which he was able to approach his supervisor and was actually assigned the task to re-write his own job description, an actualization of his reclamation of control over an otherwise perceivably uncontrollable situation as he cited that he was "lucky" the following happened:

...my manager [reviewed] the job description and agreed that this was not what they do on a daily basis. [She then asked me], "can you then please write out the actual job 
tasks?" So I wrote down the job tasks [and] gave it to the HR department, and they were able to change the job description [...] This was a relief for me because by that time, I knew that, okay, I am 100\% sure that I will apply for my PR. I will be able to get it because it fits exactly the job description that is in the NOC.

In the case of Participant \#3, after exploring his options "for better money" with several jobs and having "already seen some stability," he decided to call a former employer, who ended up offering to re-hire him. At this point, the idea of permanent residence that was previously at the back of his mind was making its way to the forefront. Participant \#3 negotiated with his employer that he would only return in "a different capacity" — into a position that was "full-time continuing":

I [first] had to convince him that he wanted me back. And it became clear that he did want me back, because I had a very specific skillset that he didn't know anyone else had. I said, "if I come back [...] this has to be a full-time continuing position with this title, with this requirements [...] to fit this particular NOC code." And he said yes.

Thus, in these moments of stasis, both participants were able to tip the scale in their favour by drawing upon their 'human resources' of skillsets and their individual foresight mobilize imaginative courses of action quite imaginative courses of action, readjusting themselves onto the path towards permanent residence.

\section{Balancing pursuits with income needs}

Some participants juggled multiple jobs in order to balance their search for skilled employment and the immediate need for income. These instances of 'survival' jobs that participants took reflects their decision to engage in work that would not qualify them for permanent residence, but was required as per their decision to support their day-to-day lives; an illustration of individual agency relatively less overpowered by state regulation.

Participant \#4 was at one point managing three part-time positions, two of which were not eligible for permanent residence to support the third job she was using to qualify: 
So over the past couple of years I also held another job [...] so at some point, I was working like three jobs, technically. So what I would do is wake up in the morning, handle that job in the morning because it's essentially online stuff [...] so I did quite enjoy that job, I just didn't like the structure of it because it was very - there was no office, it was a virtual company [...] and I just found that the communications pipelines just wasn't good enough [...] I would be at my other job and they're like, "could you jump on this?" [...] [for second job] I would do a one to five, I usually get 20 hours a week from there $[\ldots]$ and my availability for [third job] is in the evenings. So that's what my schedule was set up like.

During his six-month job search after graduation, Participant \#1 took on several jobs

which he describes just as elaborately as Participant \#4:

[I went to] this [manual] labour agency that helped any people who want to work just day to day, have some cash on a daily basis. You go to this agency early in the morning at 5 $[\ldots]$ this agency receives orders for work, or calls for work; then they distribute the tasks accordingly, depending on how many people they have per day. So I was there-it was maybe on a first come, first serve basis, so I had to be there on time, I had to be there among the first people who arrived [...] And then, by myself I applied for one other job that was handing out newspapers to people outside. How I [got this job]: I simply wentI saw people outside doing the same job, and I went to them and asked [...] they told me, "go to this website [and] apply with your resume" And I did that - I applied, and got a response within two days. They asked me to start after a week. I did that [for seven months].

Moreover, Participant \#1 talked about how he made his decision to prioritize work over

developing social networks:

I was aware at that time that I had to build social networks, but on the other hand, I was tied by the fact that I had to find survival jobs to pay bills. I had to choose [between] going for volunteering to build social networks and starve, or go and work [...] I needed a secure income. I couldn't afford to just go volunteering for four months or five months and building this network that will eventually help me to find a job in my field.

During an intensive job pursuit in which he ultimately applied for "209 jobs," yielded "4 interview calls," and no success, Participant \#3 described how he had consciously suspended his desire to pursue permanent status over finding any work. Thus, unlike the rest of the participants, his pursuit for permanent residence had zero influence over his job search; but it is because of 
this same pursuit he deemed himself at that point as "not having the luxury," nor the "stability" and "confidence" to think about permanent settlement:

I didn't get a single job offer. And that's disheartening. When you go through that, you don't - it's not important what kind of job it is anymore, because what I thought was that I'll figure out my PR later. Because I've just been rejected 209 times; 205 of those times was not even with an interview call. So you know, suddenly you think, "let me get a job first and then figure it out. I'll make it so that I'll get promoted enough to get a NOCI'll figure out." [...] It's not easy; and because of that, for me it meant I had to shift my priorities [...] I knew I was going to stay for three years at least. But now it became, "well, if I'm going to stay here, how am I going to live here." That became my primary focus.

Participant \#3's experience, as well as that of Participant \#1 in his decision to 'reject' networking over having to work, can be explored by teasing out the dominant structures at play: that of immigration and that of labour. By consciously suspending an intention based on immigration and concentrating their efforts in finding work, they interrupt the otherwise harmonious relationship between immigration and labour in shaping their realities.

Specifically for Participant \#3, his description of the pursuit for permanent residence as requiring 'stability' and 'luxury'16 reflects the intersection of structures in that he decides to claim 'resources' from the structure of labour before transposing it as a strategy towards permanent residence. When he finally did have the stability and the luxury, he allowed himself to "be strategic" - after negotiating with his old employer to re-hire him into a position that guaranteed his chances for permanent residence, he made the decision to quit, a decision that had nothing to do with immigration but with "internal politics" at the workplace, and the unsatisfying job pay and lifestyle. This is in spite of being inches away from hitting his one-year mark and

\footnotetext{
${ }^{16}$ Participant \#3 did not specify what he meant by 'luxury.' For the purpose of this analysis, it is most likely that he is referring to the ability to plan for the application to permanent residence, and throughout our conversation he insinuates that being 'able' to think about permanent residence involves a degree of risk, warranting some type of failsafe. Based on his consequent course of action in which he strategizes the 'right timing' to negotiate his return with his old employer, 'luxury' may entail time vis-à-vis the need to work to earn immediate income and some degree professional leverage (the need to be in a place where his professional skills and credentials are in enough demand).
} 
fulfilling the requirements needed to apply through Express Entry; none the less, this is was a planned move. Participant \#3 expressed that he felt he had finally had "the luxury to be calculative about [his] actions" and had "timed his decision right":

I said, "okay, it's not the end of the world. This is still going to give me what I want, but let me see if I can get what I want through another way." And I did, I got [another] job. I took my time, I looked for like three, four months; I really took my time. I didn't jump into anything and I found the right fit at the right time [...] knowing it would qualify me for PR, knowing it would give me the time to focus on the things I enjoyed outside of work.

In saying that he had "the luxury" to "be strategic" points to a change in his social position over time, a nod to the differential capacities of agency at different social positionalities: upon graduation he was solely preoccupied with looking for 'any job,' and was eventually able to mobilize his agency in a different capacity once he found 'stability' and 'better money' over time. In addition, this represents what was previously examined as the successful transposition of resources from the structure of labour into that of immigration.

\section{Re-framing mindsets}

As aforementioned, constrained subjectivities work in the favour of the power-yielding state to render subjects as dependent on the state. Participants exhibited immense resilience to reframe their mindsets - mentalities and emotions - in order to push through when confronted with feelings of 'confinement' or unable to 'move forward,' thereby exhibiting "creative transposition" (Sewell, 1992: 20) of situations that is otherwise out of their hands.

As much as time had a pronounced regulatory effect throughout the experiences of Participant \#4 and Participant \#2, it continues to do so in their current realities. While decisions on their applications are pending, both participants expressed feelings of 'liminality,' in which the uncertainty of their statuses is withholding their plans for the near future. However, 
Participant \#2 feels 'blissful,' and recognizes that there is nothing she can do now but wait; that "the ball's in their [the state's] court":

....right now I just need to get this document because I start planning [pause] it's going to be based on the fact I get PR status. If I don't get PR status, it's going to hurt me more. So I'm kind of wary of planning that much, right now. [...] all I can do is wait, which is kind of like a blissful feeling [...] but I don't feel bad because I'm just waiting now. I've done what I can and it's their decision.

The same goes for Participant \#4, who at the time of our interview was on implied status waiting to receive her bridging work permit. The wait proved "frustrating" as she feels unable to move forward, particularly as she requested a change in address a month prior but has not received any response, regardless of multiple attempts to reach Immigration, Refugees and Citizenship Canada (IRCC) by phone and having sent in two requests for address changes. This echoes her previous admission of feeling 'confined' throughout the application process:

....right now I' $m$ in a position where if I get a new job today, and I have to present them with proof, official proof with a document, I can't. So, again, I'm feeling trapped. It's just like, "why has no one gotten back to me?" [...] and right now, I don't even know what's going on, I have no idea what's going on because no one has gotten back to me [...] I'm not freaking out because I'm legally in the country, but I'm trying to get my life together.

In the bigger picture, while she does feel 'held back' and 'trapped,' Participant \#4 called her situation as "a transition phase in so many ways," and "in seeing how [it] goes," implied that this 'state' is one she is merely passing through, another minute but meaningful act of "some measure of agency in the conduct of [her] daily life" (Sewell, 1992: 20):

...in the sense that I'm kind of pending on my PR - and waiting for my PR I find that it's holding me back from doing a lot of things; I want to learn how to drive, but do I bother starting that process if I'm not $100 \%$ sure if I'm going to be in the country? And I'm just trying to figure out my career, I'm trying to lose weight, there's just so many things! [laughs] I just moved in with my boyfriend and we're trying to make plans together [...] but it can be tricky making plans with someone if you don't really know what you're doing with yourself, you know what I mean? So I'm very much in that transition phase right now where I'm just trying to figure everything out. So, yeah, hopefully we'll see how that goes. 
In the face of dilemmas posed by the specificity of employment, both Participant \#1 and Participant \#2 purposively set about to redefine their mindsets. Participant \#1's primary goal of achieving permanent residence status, which he established for himself prior to arriving to Canada as a student, eventually trumped his desire to stick to his original career trajectory as he was not successful in securing any positions in his field following graduation. With an established education and training history in a specified field that he had started prior to his studies; as well as the belief that he could begin his intended career in Canada, this change in approach was initially "hard to accept," but was eventually overcome via a reclamation of the change as a worthwhile strategy to achieve his original objective:

So for me, in trying to just accept that, okay, there is no other possibility to work in this field; it took me maybe two or three months to accept this. It was a hard decision to make, and in time, when I accepted it, I moved on. I said, "okay, let's focus on another thing-I want to become a permanent resident." This was an objective [from the beginning] [so] as long as I secure a job that would allow me to become permanent resident, I don't mind this change. Yes, it took me time to accept it, but once I accepted it, it was okay

Confronted with a double-edged employment opportunity that did not initially qualify for permanent residence that none the less appealed to her professional prospects, Participant \#2 hesitantly secured the position. Until the internship was eventually extended and met the qualifications for permanent residence, Participant \#2 expressed feeling constantly “worried," going as far as impacting a 'group learning experience' part of her internship in which she had to organize a trip for a group of students. Participant \#2 nonetheless negotiated by deciding to go through with the experience anyway by re-framing it as an opportunity to enrich her resume:

I was not in the right state. I was not in the position to lead a group of students, when I myself needed some leadership. But I did that program because I was like, "well, this is going to look good on my resume, and this is something I wanted to develop." 


\section{Reflecting back on experiences}

The trajectories to permanent residence for all participants can be understood as a constant flux between individual agency and structural regulations that contain subjects in realities of temporariness. Within this process, temporariness is an extension of the state wherein lies a large concentration of power and resources regarding social membership and labour market integration that ultimately serve to regulate those who seek permanent status in Canada.

While participants enacted their agency in 'structured ways' in order to achieve their goal of permanent status; and their experiences are more of success stories, they are able to none the less "reflexively monitor" (Turner, 1986:973) their interactions with the state to rationalize why they had to do what they did, all the while problematizing the following certain aspects of the structure as per their personal experiences.

In light of the challenges they have experienced, some participants understood that the Canadian immigration system entails an elaborate process in which 'non-Canadians' have to be screened, and that high regulations and strict controls are warranted:

...I get it, I'm not originally from Canada. They gotta veto who comes in the country. They can't just let every Tom, Dick, and Harry come in, so there has to be a process and I understand that $[\ldots]$ they gotta control it somehow. (Participant \#4)

I don't think any country would be at fault for saying, "look, we care for the people that are staying here," and that's okay, that's not wrong of any country to say. It might be less right or more right, but it's not wrong. (Participant \#3)

None the less, for Participant \#4, having a complicated process means that there needs to be "resources" in place to help. The lack thereof, particularly from the IRCC, is what she expressed as her biggest grievance:

[...] this isn't something that's straightforward, it's really not. Like you're literally applying to become a member of a country. It's a big deal. I get it if you need to put policies in place, the points system and English tests and all that, which is why people do it, because that's just what's gotta be done. But why is it so hard to get help? Why is it 
when I email IRCC, I don't get a response? Why is it when I call, I never get to talk to somebody? There's just no resources. I just don't see why it should be so painful. The process is already painful enough. You should be doing what you can in your power to make things easier for me, and I just feel like they don't.

Similarly, Participant \#3's own grievances are based on the bureaucratic fallbacks of the

system, particularly in its backlogs and delays, which he believes hurts people and their plans:

...the system itself didn't give what was promised. What was promised was [that] [...] in two weeks, you're given an invite. It wasn't two weeks for people, it was four to five months. And if you're given a permit for three years and you're only able to get [work] experience after two years, a four-month delay is coming pretty close to the end of your permit, and what do you do at that point? [...] there are skilled people who by that time has spent seven years in this country and are positive contributing members, paying taxes, spending $\$ 100,000$ in tuition money, and suddenly their futures are being jeopardized, and that's not okay. I understand it's a bureaucracy and everything, but making promises that can't be kept isn't fair either. Because if people would have known it might take six months to get your Express Entry invitation, then people would have prepared for that.

Some participants recognized that the system working for individuals like them was also

an inequality in itself, and reflected upon their upbringing, which Participant \#5 describes as

"digestable for those who are in power":

I mean, am I happy about the points system and about the economic classes? You know, it's very interesting. I could definitely, hopefully, become slightly more successful than other international students. I'm lucky enough to not have a quote-unquote accent-but really, I have a North American accent - and I am more acculturated [to Canada] than other people. These are comments I hear from people all the time [...] but really, my story is the same as a lot of people [in that] we all want to find a better life here. So do I see the system as unfair? Yeah, I really do [...] I really see the points system as very much for folks who have better access [...] I was able to, because of my privileges, become more digestable from the eyes of those who are in power here.

With getting help from the IRCC being her biggest frustration, Participant \#4 thought

about what the experience would be like for others with a different upbringing:

You can barely reach [IRCC], but that one time, [they] were so rude and not even helpful at all. And like this is [sighs] it's just so frustrating. Like I can only imagine somebody who called them with a strong accent, like if I was to call them and just speak in my local accent, I feel like they would be even more rude to them [...] coming from someone who is educated, a lot of [the process has] been me just going on a whim, hoping everything 
will be okay and just using my own common sense [...] but if I was to call them and I was somebody who really didn't know the process and I'm trying to get answers? They can't provide you with answers, man.

Finally, there were some reflections grounded in connections between immigration and Indigeneity in Canada. Participant \#2 communicated that it was recent that she became involved in dialogue regarding the history of indigenous genocide and their current experiences in the current national landscape. She sees this as another 'gap' between the 'ideal immigrant' rhetoric and reality, in terms of "welcoming international students to apply to stay permanently" while "not even having contact with some of the Indigenous peoples in Canada":

I think it is a problem [...] I think that's something I will probably continue to think about if I become a permanent resident and I think there's a really intricate power play there $[\ldots]$ that's something that will only become more prevalent as more foreign students decide to stay on, or other foreign nationals, I guess, decide to pursue permanent residency [...] I was surprised to not come across this while I was a student, actually. But me telling my friends that I'm trying to do this and I want to stay here, and them telling me about their experience. It was such a different story [...] I don't know, it was strange. We're in the same place, but we come from such different backgrounds, and we're trying to do different things but [they] have something to do with the Canadian government. I don't know if it's actually conflicting or clashing, it's just like [there's] no cross point, just going different directions, but we are living together in the same Canadian society.

Participant \#5 found it "unfair" that immigration is premised upon the idea of 'benefitting

the nation,' without being critical of 'whose nation':

Who gets to make these decisions? They say it's for benefitting the country, the nation. Oh, really? What nation are you talking about, who nation is it? [...] in a perfect world, I would love it if immigration is completely $100 \%$ handled by Indigenous folks from the many different nations [...] I would love to see this points system as a "points system" for how respectful we are towards the Indigenous people of this land, and we are giving back? Are we respecting the land? Are we respecting cultures and each other? Because there is definitely an economic benefit to that [approach], for sure, it just has to be [within] a different economic system. I would love it if the Indigenous people of this land are the ones making the decision to whether I can stay or not long-term. 


\section{Discussion of Findings}

As much as the Post-Graduation Work Permit is marketed as the international student advantage, it also the means by which the state ensures it retains its advantage over international students. What results is a contradictory logic that eventually works to the benefit of the state the neoliberal 'ideal immigrant' rhetoric can be understood as an materially and emotionally oppressive containment of former international students within the space of temporariness, as the ultimate key to staying permanently in Canada is in the hands of the state, in that of the employer via instruments such as job descriptions, and in those of the larger labour market as they are required to find not just any occupation, but one that is 'skilled.'

At the same time, the fact that subjects remain within this contained space, attain the required qualifications and push through the challenges in order to achieve permanent status is also in a sense an adherence to the 'ideal immigrant' rhetoric; a reproduction of the 'good (neoliberal) citizen' who not only abides by the terms of her temporariness, but strives to embody the very 'self-reliance' valorized by neoliberalism. As long as subjects enact 'structured' agency and knowledge to pursue permanent residence status in authorized ways, there is not much room to discursively and materially reject this space, as to do so would be to not pursue permanent residence, to leave the country, or even, to not abide by the terms of one's permit, such as overstaying or engage in unauthorized work.

However, adherence to the structure may only be the case until status is achieved, as participants' reflections on their experiences reveal the many grievances they possess about their experience, as well as astute awareness of the inequalities imbued within the system from which they ultimately benefit. In understanding that structures are dual, while participants enact their agency within the structure, it is the structure ultimately allows participants to enact their agency 
in new and larger capacities once they acquire their permanent status. The reflexivity participants demonstrate in their reflections are hopeful, given the duality, and thus, mutability, of structures,

Once achieved, permanence is a resource participants can use to act upon their reflections and set meaningful changes in motion, if not simply 'pay it forward' and act as a pillar of support to others. Until then, adherence should not be seen as fixed nor perpetual, but perhaps a long-term strategy in itself.

\section{Limitations and future research}

Moving forward, the primary limitation of this analysis is its scope of generalizability. This was a look at the micro-level experiences of temporariness, as experienced by a specific international student demographic for whom the immigration has 'worked;' thus it cannot speak to the experiences of the thousands of other international students in Canada. Especially for conversations on where the system requires further improvement, or what is truly missing from the framework of support in the post-graduation experience, potential areas for future investigation includes the experiences of those who were not able to achieve permanent status due to rejected applications, permit expirations, or even personal decisions to leave the country.

Moreover, because of the 'success stories' this study portrays, this is just a small piece in the bigger patchwork of temporariness in Canada. It is thus not representative of those who are temporary and are in more vulnerable and precarious situations; situations in which time limits translate to not merely the need to leave the country, but to higher risks of criminality such as deportation or incarceration, there is no option of employment, let alone 'skilled employment,' and the terms of ascribed temporary legal statuses are materially and emotionally constraining in ways far beyond the experiences shared for this study. 
Another significant limitation of this study is the lack of a holistic integration of participants' pre-Canada trajectories, specifically the colonial histories of their countries of origin. It is integral to recognize that any decision to study abroad and to pursue permanent residency status is not entirely an individually-driven process, but one that takes place within a larger globalized context of migration flows; from 'source countries' that were once subjugated under the imperial control of today's major 'destinations of study.' While this study attempted to document the micro dynamics of individual decision-making and subsequent courses of action, and has contextualized economic immigration in Canada today with its own history of exclusion, I wish to at least acknowledge that behind the decisions and actions of every human subject engaging within one national history are too shaped by different and undoubtedly complex histories.

The above limitations give way to a grand scope of opportunities for future research. Alongside looking into the post-graduation experiences of a wider variety of international students seeking permanent settlement in Canada, there are two areas I would have liked to go into further for this study, but was not able to due to constraints in time.

The first is a deeper look into subjectivities and structures' influences on how participants view their realities. While I did include instances in my analysis, it would be worthwhile to dedicate a study focused on the internalization of structural effects. A possible framework is a deeper look at immigration as a process of social integration and national membership, and how this plays upon individuals' identity-making processes and feelings of belonging vis-à-vis their pre-migration biographies.

The second area I recommend for future research involves a more elaborate unpacking of temporariness with an emphasis on the multiplicity and intersections of structures. An 
exploration of this entail a combination with an intersectional framework to calculate the different backgrounds of each participant into how experiences are shaped in their immigration trajectories, as well as the forms of power inequalities and structural oppression that manifest in their day-to-day realities. This can go one step further by strongly considering the ways temporariness is experienced differently from different migrant groups. 


\section{CONCLUSION}

International students are a mobile population, making temporariness the medium in which they pursue international education in Canada while remaining nationally tied to their countries of origin. Further, they are wanted for their economic benefits, and are afforded the exclusive opportunity to enter the labour market; but when it comes to being permanent members of Canada, they must none the less be 'legitimized' as such. This study explored that legitimization of via the micro-level experiences of former international students pursuing permanent residence status. Recognizing Canada as a power-yielding state provides an understanding of how immigration today works to control and contain non-Canadian subject realities as temporary. Structuration theory was employed to explore these subjects as active human agents, capable of negotiating their agency with structural constraints in order to achieve their goal of permanence in Canada.

Barriers of lack of work experience, networks, and gaps in service provisions as cited in the literature review were less pronounced in participants' experiences, but state regulation as manifested in time limits, the specificity of qualifying employment and the material, mental and emotional challenges posed by their temporary legal statuses proved to be greater challenges, imposing emotional toll and unexpected contingencies. While engaging in this race against time, participants employed innovative strategies in their pursuit for qualifying work and pragmatism in order to balance long-term goals with the immediate need for income, and strive to overcome material and mental barriers by reconstructing their mindsets. Participants demonstrate perseverance and resilience as they remain 'on their feet' and flexibly strategic in the face of challenges, all the while striving to keep emotional and mental defeats at bay. What this study especially captured are various forms of emotional labour, such as feelings of entrapment and 
instability, engagements with self-blame and references to 'luck,' intangible experiential elements that accompanied decisions and subsequent courses of action. In looking back, participants were able to impose meaning onto their experiences and are able to ultimately render their pursuits for permanence as a smaller stepping stone to a greater personal goal, whether it is to return to school, staying with the ones they love, or simply striving for greater stability.

This study contributes to evidence of a disconnect between state perceptions of international students and their actual lived experiences. Part-time and precarious work is a problem common to most Canadian youth (ages 15 to 24). As the 'preferred' immigrants, international students fare better than most temporary migrants; but in comparison to their Canadian and permanent resident counterparts, among whom part-time and precarious work in the first years of entry into the labour market is an established problem (Lamb and Doyle, 2017), the stakes have been made far higher and arguably far less reasonable by virtue of their disadvantageous legal status, imposed time and employment limits, and the general landscape of service provisions. Moreover, Canada's history of whiteness also informs the view of temporary migrants as the presence of 'others' in Canada's national space - modern nation-states and their borders are simply reiterations of historical dynamics of exclusion and exploitation, through and within which the "unequal exchange of resources and power" are "further reproduced" (Fobear, 2014:n.p.). Indeed, taking it "as a given" (Gates-Gasse, 2012:274) that international students are capable of integrating into the labour market is, on the part of immigration policy and practices, is at least negligent, if not a purposive yet subtle re-run of history in which privilege and power works to exclude the 'undesirable' from the 'preferred.' 


\section{APPENDIX}

\section{Interview Guide: Demographic \#1}

1. Have you decided to apply for permanent residence/have you already applied for permanent residence?

2. When did you decide you wanted to be a permanent resident in Canada?

a. Probe/follow-up: Can you describe how you came to this initial decision?

b. Probe/follow-up: Was it part of your decision to study in Canada?

3. How far along are you in your preparation for applying for permanent residence?

a. Probe/follow-up: What did you have to do to get to the point you are today?

b. Probe/follow-up: How has the process been like so far?

c. Probe/follow-up: How is everyday life like nowadays?

d. Probe/follow-up: Have you thought about seeking professional or legal consultation?

e. Probe/follow-up: How informed were you about the immigration process at the beginning of your post-graduation experience? As a student?

4. What are your plans moving forward, especially when you get your permanent residency?

a. Probe/follow-up: Do you see yourself eventually getting citizenship?

b. Probe/follow-up: What does permanent residence status mean for you?

5. Looking back, how would you describe your experience in Canada?

a. Probe/follow-up: Is there anything you would have done differently?

b. Probe/follow-up: How would you evaluate the Canadian immigration system?

6. What would be your advice to international students hoping to get permanent residence themselves?

\section{Interview Guide: Demographic \#2 ${ }^{17}$}

1. When did you get permanent residence status? How?

a. Probe/follow-up: How long did the entire process take?

b. Probe/follow-up: How was the process like?

c. Probe/follow-up: How was everyday life like?

2. When did you decide you wanted to be a permanent resident in Canada?

a. Probe/follow-up: Can you describe how you came to this initial decision?

b. Probe/follow-up: Was it part of your decision to study in Canada?

c. Probe/follow-up: Did you seek professional or legal consultation?

d. Probe/follow-up: How informed were you about the immigration process at the beginning of your post-graduation experience? As a student?

\footnotetext{
${ }^{17}$ The Interview Guide for Demographic \#3 is not included as I did not recruit any participants from my third demographic target.
} 
3. Can you describe what it was like when you finally got your status?

a. Probe/follow-up: Can you compare your experience applying for permanent residence to life nowadays?

b. Probe/follow-up: Are you working in the same job as you were before you got permanent residence?

c. Probe/follow-up: What are your plans now? Do you see yourself eventually getting citizenship?

d. Probe/follow-up: What does permanent residence mean to you?

4. Looking back, how would you describe your experience in Canada?

a. Probe/follow-up: Is there anything you would have done differently?

b. Probe/follow-up: How would you evaluate the Canadian immigration system?

5. What would be your advice to international students hoping to get permanent residence themselves? 


\section{BIBLIOGRAPHY}

Arat-Koc, S. (1999a). Gender and race in "non-discriminatory" immigration policies in Canada. In Robertson, A., and Dua, E. (Eds.), Scratching the Surface: Canadian Anti-Racist, Feminist Thought, (pp. 207-233). Toronto: Women's Press.

Arat-Koc, S. (1999b). Neo-liberalism, state restructuring and immigration: changes in Canadian policies in the 1990s. Journal of Canadian Studies, 34(2), 31-56.

Arthur, N., \& Flynn, S. (2013). International students' views of transition to employment and immigration. The Canadian Journal of Career Development, 12(1), 28-37.

Austin, C. and Bauder, H. (2012). Jus domicile: a pathway to citizenship for temporary

foreign workers? In Bauder, H. (Ed.), Immigration and Settlement: Challenges, Experiences, and Opportunities, (pp. 21-36). Toronto: Canadian Scholars' Press.

Bauder, H. (2008). The economic case for immigration: neoliberal and regulatory paradigms in Canada's press. Studies in Political Economy 82(2), 131-152.

Bond, S. (2007). Northern lights: international graduates of Canadian institutions and the national workforce. Retrieved from http://books.scholarsportal.info/viewdoc.html?id=32473.

Cameron, J. D. (2006). International student integration into the Canadian university: a post-World War Two historical case study. History of Intellectual Culture, 6(1).

Canadian Bureau for International Education (CBIE). (2015). Facts and Figures: Canada's Performance and Potential in International Education 2015. Retrieved from http://cbie.ca/media/facts-and-figures/.

Canadian Council for Refugees (CCR). (2016a). Migrant workers: precarious and unsupported: a Canada-wide study on access to services for migrant workers. Retrieved from http://ccrweb.ca/sites/ccrweb.ca/files/migrant-workers-2016.pdf. 
Canadian Council for Refugees (CCR). (2016b). Temporary Foreign Worker Program: a submission by the Canadian Council for Refugees to the Standing Committee on Human Resources, Skills and Social Development and the Status of Persons with Disabilities. Retrieved from http://ccrweb.ca/en/submission-TFWP-review.

Cobb, M. A. (2012). Exploring barriers for international students transitioning to labour force attachment: a case study on Prince Edward Island. (Thesis). Retrieved from http://vre2.upei.ca/islandscholar/fedora/repository/ir\%3A5039.

Cohen, N. and Arieli, T. (2011). Field research in conflict environments: methodological challenges and snowball sampling. Journal of Peace Research 48(4), 423—435.

Cox, C. (2014). International students in Canada: policies and practices for social inclusion. (Major research paper). Retrieved from Ryerson Digital Repository.

Crowley, B. L. (2014, January 24). Crowley in the globe: In foreign-student gold rush, standards get left behind. [Blog post]. Retrieved from http://www.macdonaldlaurier.ca/crowleyin-the-globe-in-foreign-student-gold-rush-standards-get-left-behind/.

Dua, E. (1999). Canadian anti-racist feminist thought: scratching the surface of racism. In In Robertson, A., and Dua, E. (Eds), Scratching the Surface: Canadian Anti-Racist, Feminist Thought, (pp. 7-31). Toronto: Women's Press.

Fama, M. (2011). A new era for Canada's international student program. Canadian Diversity, 8(5), 11-14.

Fobear, K. (2014). Queer settlers: questioning settler colonialism in LGBT asylum processes in Canada. Refuge, 30(1). 
Fudge, J. and Macphail, F. (2009). The Temporary Foreign Worker Program in Canada: low-skilled workers as an extreme form of flexible labour. Comparative Labour Law and Policy Journal 31(5), 5-46.

Galletta, A. (2013). Introduction. In Mastering the Semi-Structured Interview and Beyond: from research design to analysis and publication, (pp. 1-6). New York: NYU Press.

Gates-Gasse, E. (2012). International students as immigrants. In Bauder, H. (Ed.), Immigration and Settlement: Challenges, Experiences, and Opportunities, (pp. 271 - 296). Toronto: Canadian Scholars' Press.

Government of Canada. (2008, April 21). Archived - Government of Canada introduces changes to work permits for international students, making Canada more attractive for skilled individuals. Retrieved from http://news.gc.ca/web/articleen.do?crtr.sj1D=\&crtr.mnthndVl=4\&mthd=advSrch\&crtr.dpt1D=\&nid=393209\&crtr.lc1D=\&crt r.tp1D=\&crtr.yrStrtVl=2008\&crtr.kw=Post-

Graduation+Work+Permit\&crtr.dyStrtVl=21\&crtr.aud1D $=\& c r t r . m n t h S t r t V l=4 \& c r t r . p a g e=3 \& c r t$ r.yrndVl=2008\&crtr.dyndVl=22.

Government of Newfoundland and Labrador. (n.d.). Newfoundland and Labrador Provincial Nominee Program - International Graduate. Retrieved from http://www.nlpnp.ca/student.html.

Government of Saskatchewan. (n.d.). Students. Retrieved from http://www.saskatchewan.ca/residents/moving-to-saskatchewan/immigrating-tosaskatchewan/saskatchewan-immigrant-nominee-program/applicants-with-saskatchewanexperience/students. 
Gürüz, K. (2011). International student mobility. In Higher education and international student mobility in the global knowledge economy, (pp. 201-313). New York: State University of New York Press.

Immigration, Refugees and Citizenship Canada (IRCC). (2017a, September 1). Designated learning institutions list. Retrieved from http://www.cic.gc.ca/english/study/studyinstitutions-list.asp.

Immigration, Refugees and Citizenship Canada (IRCC). (2017b, July 28). Find out if you're eligible-Post-graduation work permit. Retrieved from http://www.cic.gc.ca/english/study/work-postgrad-who.asp.

Immigration, Refugees and Citizenship Canada (IRCC). (2017c, June 28). Express Entry-Comprehensive Ranking System (CRS) Criteria. Retrieved from www.cic.gc.ca/english/express-entry/grid-crs.asp

Immigration, Refugees and Citizenship Canada (IRCC). (2017d, May 19). Caregivers. Retrieved from http://www.cic.gc.ca/english/immigrate/caregivers/index.asp.

Immigration, Refugees and Citizenship Canada (IRCC). (2017e, February 9). What is Labour Market Impact Assessment? Retrieved from http://www.cic.gc.ca/english/helpcentre/answer.asp?qnum=163\&top=17.

Immigration, Refugees and Citizenship Canada (IRCC). (2016a, November 19). How Express Entry Works. Retrieved from http://www.cic.gc.ca/english/express-entry/.

Immigration, Refugees and Citizenship Canada (IRCC). (2016b, November 9). The application process for provincial nominees. Retrieved from http://www.cic.gc.ca/ENGLISH/immigrate/provincial/apply-choose.asp. 
Immigration, Refugees and Citizenship Canada (IRCC). (2016c, October 31). 2016

Annual Report to Parliament on Immigration. Retrieved from

http://www.cic.gc.ca/english/resources/publications/annual-report-

2016/index.asp? ga=1.204889491.2036318808.1449287296\#s1.2.

Immigration, Refugees and Citizenship Canada (IRCC). (2016d, March 18). Evaluation

of the Canadian Experience Class. Retrieved from

http://www.cic.gc.ca/english/resources/evaluation/cec/2016/index.asp.

Immigration, Refugees and Citizenship Canada (IRCC). (2012, October 1). Fact SheetTemporary Foreign Worker Program. Retrieved from

http://www.cic.gc.ca/english/resources/publications/employers/temp-foreign-workerprogram.asp.

Iturralde, C. and Calvert, C. (2003). Foreign students in Canada 1980 - 2001. Priorities, Planning and Research Branch, Citizenship and Immigration Canada. Retrieved from http://open.canada.ca/vl/en/doc/collections-20047020016.

Kelley, N. and Trebilcock, M. (2010). The Making of the Mosaic: A History of Canadian Immigration Policy. Toronto: University of Toronto Press.

Kelly, M. (2017). The bureaucratic organization of race in deportation and Canadian immigration policy. (Major Research Paper). Retrieved from Ryerson Digital Repository.

Kelly, N. T. (2012). International students as immigrants transition challenges and strengths of current and former students. (Major Research Paper). Retrieved from Ryerson Digital Repository.

Lamb, C. and Doyle, S. (2017). Future-proof: preparing young Canadians for the future of work. Retrieved from http://brookfieldinstitute.ca/research-analysis/futureproof/. 
Latham, R. et. al. (2014). Introduction: liberating temporariness? Imagining alternatives to permanence as a pathway for social inclusion. In Vosko, L., Preston, V. and Latham, R. (eds.), Liberating Temporariness? Migration, Work, and Citizenship in an Age of Insecurity, pp. 3-31.

Lu, Y., and Hou, F. (2015, December 10). International students who become permanent residents in Canada. Insights on Canadian society. Retrieved from http://www.statcan.gc.ca/pub/75-006-x/2015001/article/14299-eng.htm.

Marginson, S. (2011). Including the other: regulation of the human rights of mobile students in a nation-bound world. High Education, 63(4), 497—512. doi: 10.1007/s10734-0119454-7.

Nunes, S. and Arthur, N. (2013). International students' experiences of integrating into the workforce. Journal of Employment Counselling, 50(1). doi: 10.1002/j.21611920.2013.00023.x.

Organisation for Economic Co-operation and Development (OECD). (2015). Education at a Glance 2015. Retrieved from http://www.keepeek.com/Digital-AssetManagement/oecd/education/education-at-a-glance-2015_eag-2015-en\#page354.

Organisation for Economic Co-operation and Development (OECD). (2011). Education at a Glance 2011. Retrieved from http://www.keepeek.com/Digital-AssetManagement/oecd/education/education-at-a-glance-2011_eag-2011-en\#page331.

Province of Alberta. (2017, March 1). Employer Driven Stream. Retrieved from http://www.albertacanada.com/opportunity/programs-and-forms/ainp-eds-employer-drivenstream.aspx. 
Province of British Columbia. (2017). International Graduate. Retrieved from https://www.welcomebc.ca/Immigrate-to-B-C/BC-PNP-Skills-Immigration/InternationalGraduate.

Province of Manitoba. (n.d.). Determine your eligibility - skilled workers in Manitoba. Retrieved from http://www.immigratemanitoba.com/immigrate-to-manitoba/swm/swmeligiblity/.

Province of Ontario. (2017, January 19). Ontario Immigrant Nominee Program - What is the International Student with Job Offer stream? Retrieved from http://www.ontarioimmigration.ca/en/pnp/OI_PNPSTUDENTS_JOB.html.

Rajkumar, D. et. al. (2012). At the temporary-permanent divide: how Canada produces temporariness and makes citizens through its security, work, and settlement policies. Citizenship Studies, $16(3-4), 483-510$.

Roach, E. (2011). Service needs and gaps for international student transitioning to permanent residency in a "two-step" immigration process: a Toronto-based study. (Major Research Paper). Retrieved from Ryerson University Library \& Archives. (LB2376.6.C3 R63 2011).

Roslyn Kunin \& Associates. (2012). Economic Impact of International Education in Canada - An Update. Retrieved from http://www.international.gc.ca/education/reportrapport/economic-impact-economique/index.aspx?lang=eng.

Sewell, W. H. (1992). A Theory of Structure: duality, agency, and transformation. American Journal of Sociology, 98(1), 1-29. 
Siemiatycki, M. (2015). Continuity and change in Canadian immigration policy. In Bauder, H. and Shields, J. (Eds.), Immigrant Experiences in North America: Understanding Settlement and Immigration, (pp. 93-117). Toronto: Canadian Scholar's Press.

Scott, C., Safdar, S., Trilokekar, R. D., and El Masri, A. (2015). International students as 'ideal immigrants' in Canada: a disconnect between policy makers' assumptions and the lived experiences of international students. Comparative and International Education, 43(3). Retrieved from http://ir.lib.uwo.ca/cie-eci/vol43/iss3/5.

Turner, J. H. (1986). Review: The theory of structuration. American Journal of Sociology, 91(4), 969-977.

United Nations Educational, Scientific and Cultural Organization (UNESCO). (2016). Total inbound international mobile students. Retrieved from http://uis.unesco.org/indicator/edumobility-in-total.

Valiani, S. (2013). The shifting landscape of contemporary Canadian immigration policy: the rise of temporary migration and employer-driven immigration. In Goldring, L. \& Landolt, P. (Eds.), Producing and Negotiating Non-Citizenship: precarious legal status in Canada (pp. 55 70). Toronto: University of Toronto Press.

Victor, W. (2007). Indigenous justice: clearing space and place for indigenous epistemologies. Research Paper for the National Centre for First Nations Governance, 3-11.

Wolfel, R. L. (2005). Migration in the New World Order: Structuration Theory and its Contribution to Explanations of Migration. Geography Online, 5(2), 1-28.

Zilio, M., \& Chiose, S. (2016, March 14). Ottawa looks to ease international students' path to permanent residency. The Globe and Mail. Retrieved from 
http://www.theglobeandmail.com/news/politics/ottawa-looks-to-ease-international-students-pathto-permanent-residency/article29242266/. 